\title{
EFEITO DO MATERIAL DE RECOBRIMENTO NA DEFORMAÇÃO SOFRIDA POR INFRA- ESTRUTURAS DE PRÓTESES FIXAS IMPLANTO- SUPORTADAS, UTILIZANDO EXTENSÔMETROS LINEARES ELÉTRICOS
}

ANTÔNIO FRANCISCO GRANDO

Dissertação apresentada à Faculdade de Odontologia de Bauru, da Universidade de São Paulo, como parte dos requisitos para a obtenção do título de Mestre em Odontologia, área de Reabilitação Oral.

BAURU 


\section{EFEITO DO MATERIAL DE RECOBRIMENTO NA DEFORMAÇÃO SOFRIDA POR INFRA- ESTRUTURAS DE PRÓTESES FIXAS IMPLANTO- SUPORTADAS, UTILIZANDO EXTENSÔMETROS LINEARES ELÉTRICOS}

ANTÔNIO FRANCISCO GRANDO

Dissertação apresentada à Faculdade de Odontologia de Bauru, da Universidade de São Paulo, como parte dos requisitos para a obtenção do título de Mestre em Odontologia, área de Reabilitação Oral.

Orientador: Prof. Dr. José Henrique Rubo.

BAURU

2003 


\begin{tabular}{|l}
\hline G764e \\
Grando, Antônio Francisco \\
por infra-esto do material de recobrimento na deformação sofrida \\
utilizando extensômetros lineares elétricos/ Antônio Francisco \\
Grando - Bauru, 2003. \\
94 p. : il.; $31 \mathrm{~cm}$. \\
Dissertação (Mestrado) - Faculdade de Odontologia de Bauru. \\
Universidade de São Paulo. \\
Orientador: Prof. Dr. José Henrique Rubo
\end{tabular}

Autorizo, exclusivamente para fins acadêmicos e científicos, a reprodução total ou parcial desta dissertação, por processos fotocopiadores e outros meios eletrônicos. 


\section{ANTÔNIO FRANCISCO GRANDO}

Nascimento

Filiação

$1987-1991$

1991

1991

1993-1994

26 de fevereiro de 1968

lbicaré - SC

Antônio Grando

Leonor Rosa Grando

Curso de Odontologia, na

Universidade Federal de

Pelotas - RS.

Estágio de Graduação em

Odontologia nas disciplinas de Prótese Parcial I e II da Faculdade de Odontologia da Universidade Federal de Pelotas, RS.

Aprovação, em 1ำlugar, em Concurso de Seleção de Professor Substituto para contratação Temporária, nas Disciplinas de Prótese Parcial I e II do Departamento de Odontologia Restauradora, da Faculdade de Odontologia da Universidade Federal de Pelotas, RS.

Curso de Aperfeiçoamento em Prótese Dental pela APCD - Bauru, SP. 
1994-1995

1996 - até o momento

2001-2003

Associação
Curso de Especialização em

Periodontia, pela APCD -

Bauru, SP.

Professor Assistente das

Disciplinas de Prótese Fixa e Clínica Integrada do Curso de Odontologia da Universidade Paranaense, Umuarama, PR.

Curso de Pós-Graduação em

Reabilitação Oral - Prótese, em Nível de Mestrado, na Faculdade de Odontologia Bauru, USP, SP.

A.B.O. Associação Brasileira de Odontologia - Secção PR Sub Seção Oeste. 


\section{DEDICATÓRIA}

A Deus pela bênção da vida.

Aos meus pais Antônio (em memória) e Leonor que sempre com muito amor e carinho me ensinaram o caminho da simplicidade e humildade. Todas as minhas vitórias dedico a vocês que lutaram para que eu pudesse realizar todos os meus sonhos. Agradeço a Deus pela benção de tê-los como meus pais.

À Giselle, minha esposa e companheira, grande incentivadora desta caminhada, obrigado pelo amor, carinho e compreensão.

Aos meus irmãos Marlene, Arlete e José, minha eterna gratidão por proporcionarem a realização do primeiro sonho, poder fazer um curso de Odontologia.

A todos, que de forma direta ou indireta, mesmo anônimos tornaram este sonho uma realidade.

A vocês dedico este trabalho. 


\section{AGRADECIMENTO ESPECIAL}

Ao Prof. Dr. José Henrique Rubo, meu orientador, agradeço a confiança, incentivo e atenção com que me recebeu e conduziu. 


\section{AGRADECIMENTOS}

Aos professores do Departamento de Prótese da Faculdade de Odontologia de Bauru, Conti, Accácio, Pegoraro, Lauris, Renato, Lucimar, Salvador, Rubo, Carlos Araújo, pelos ensinamentos e dedicação.

Ao professor, Dr. Luiz Fernando Pegoraro, pelo exemplo de simplicidade, seriedade e dedicação ao ensino.

Aos colegas do Mestrado Interinstitucional pelo companheirismo e amizade.

Aos colegas de turma Murilo, Sávio, Rolando, Eliseu, Thaís, Clóvis, Vagner, René e Rafael, obrigado pelos momentos compartilhados.

À professora, Dr. Maria Fidela e ao Prof. Dr. Newton Expedito de Moraes, pela luta para que este curso pudesse ser realizado e, nosso sonho concretizado.

Aos amigos, Márcio e Stella, pessoas iluminadas que me brindaram com sua amizade, agradeço pela disponibilidade, e participação valorosa para que este trabalho se tornasse possível.

A todos os colegas do mestrado acadêmico pela recepção e atenção.

Às funcionárias do departamento, em especial à Edna, pela atenção com a qual sempre nos atendeu.

Aos funcionários da biblioteca, em especial à Rita e Valéria, pela atenção e orientação na elaboração deste trabalho. 
Aos mestres e mentores da minha incursão no magistério, Prof. José Carlos Maciel da Silva e Prof. João Arthur Amaral da Silva.

Ao amigo, Márcio Gramma Hoeppner, pelo constante apoio e incentivo, dentro da sua humildade e competência muito aprendi.

Aos Professores da Universidade Paranaense, pelo companheirismo e convívio. 


\begin{abstract}
À Faculdade de Odontologia de Bauru, da Universidade de São Paulo, através de sua diretora, Profa. Dra. Maria Fidela de Lima Navarro, à comissão de pós-graduação, através de seu presidente Prof. Dr. José Carlos Pereira, à Universidade Paranaense, na pessoa do Coordenador do Curso de odontologia, Prof. Dr. Márcio Grama Hoeppner, pela cessão da bolsa de estudos, à Universidade Estadual de Londrina, representada pelo Prof. Dr. Newton Expedito de Moraes.
\end{abstract}


A todos que participaram desta caminhada incentivando-me e tornando possível a realização deste projeto.

Tenham uma certeza, poderemos estar separados pela distância, porém, sempre unidos pela amizade.

Minha eterna gratidão !!!! 


\section{SUMÁRIO}

LISTA DE FIGURAS

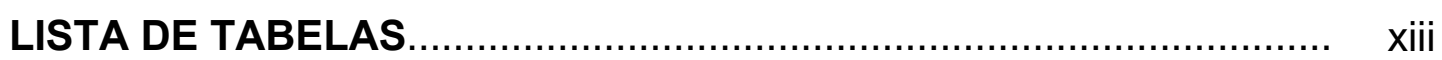

LISTA DE FÓRMULAS.............................................................. xiv

LISTA DE ABREVIATURAS ...................................................... $\mathrm{xv}$

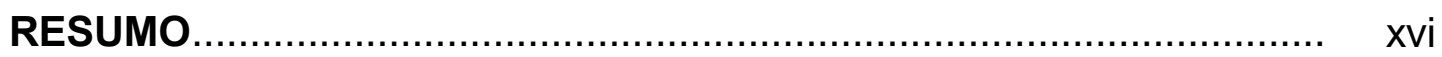

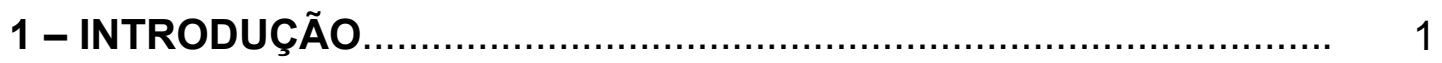

2 - REVISÃO DE LITERATURA...................................................... 4

3 - PROPOSIÇÃO.................................................................. 34

4 - MATERIAL E MÉTODOS

4.1 - SELEÇÃO DA AMOSTRA............................................................. 35

4.2 - CONFECÇÃO DO MODELO MESTRE........................................... 35

4.3 - CONFECÇÃO DO CORPO DE PROVA................................................ 38

4.3.1 - INFRA-ESTRUTURA EM LIGA DE PALÁDIO-PRATA................................ 38

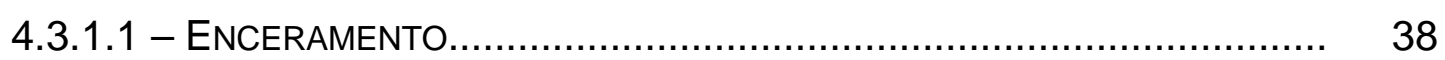

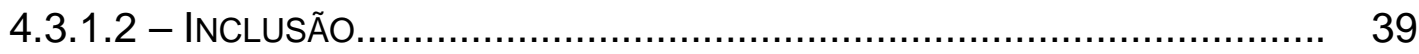

4.3.1.3 - FUNDIÇÃO................................................................... 41

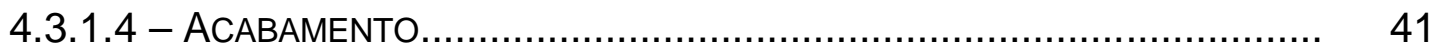

4.4 - APLICAÇÃO DO MATERIAL DE RECOBRIMENTO SOBRE A INFRA-

ESTRUTURA METÁLICA ……………………………………………... 43

4.4.1 - APLICAÇÃO DA PORCELANA ......................................................... 43

4.4.2 - APLICAÇÃO DA RESINA ACRÍLICA TERMOPOLIMERIZÁVEL..................... 44

4.5 - CoLAGEM DOS EXTENSÔMETROS LINEARES ELÉTRICOS........................ 46

4.6 - FIXAÇÃO DO CORPO DE PROVA.................................................... 47

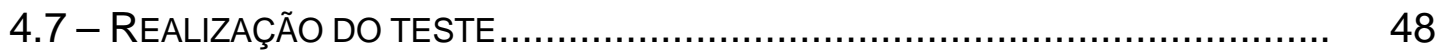

4.8 - ANÁLISE DOS DADOS............................................................... 51

5 - RESULTADOS

6 - DISCUSSÃO

7 - CONCLUSÕES

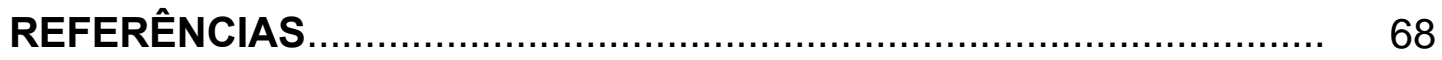

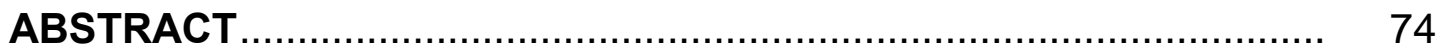




\section{LISTA DE FIGURAS}

Figura 4.1 - Desenho esquemático do modelo mestre..........................p. 36

Figura 4.2 - Dispositivo eletrônico de controle de torque..........................p. 37

Figura 4.3 - Vista superior do modelo mestre com os intermediários em posição...................................................................... 37

Figura 4.4 - Vista inferior do enceramento do corpo de prova..................p. 39

Figura 4.5 - Vista frontal do enceramento do corpo de prova no modelo-mestre

Figura 4.6 - Vista superior do corpo de prova em paládio-prata,

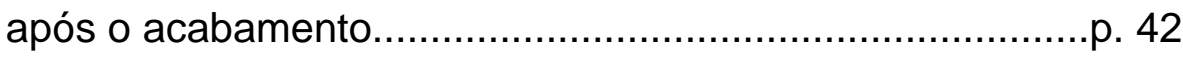

Figura 4.7 - Aplicação da porcelana ................................................p. 44

Figura 4.8 - Aplicação da resina acrílica termopolimerizável....................p. 45

Figura 4.9 - Vista superior dos extensômetros lineares elétricos.............p. 47

Figura 4.10 - Colagem dos extensômetros com adesivo a base de cianocrilato, sobre a superfície de porcelana.................p. 47

Figura 4.11 - Corpo de prova fixado ao modelo-mestre e os extensômetros lineares elétricos colados

Figura 4.12 - Aplicação da carga na extremidade livre recoberta por porcelana feldspática p. 50

Figura 4.13 - Aplicação da carga na extremidade livre recoberta por resina acrílica termopolimerizável. p. 50

Figura 4.14 - Estágios da coleta de dados pelo Lab View. p. 54

Figura 5.1 - Dados obtidos pelo teste de deformação por compressão..p. 59 


\section{LISTA DE TABELAS}

Tabela 4.1 - Especificações da liga utilizada na fundição, segundo o fabricante............................................................ 43

Tabela 4.2 - Especificações dos materiais de recobrimento segundo os fabricantes. p.46

Tabela 4.3 - Dados coletados no ensaio para análise pelo software ORIGIN p.55

Tabela 5.1 - Quadro comparativo dos índices de deformação em função do ponto de aplicação da carga.....................................p.58

Tabela 6.1 - Análise comparativa dos percentuais de deformação entre os materiais estudados p.65 


\section{LISTA DE FÓRMULAS}

Fórmula 4.1 - Fórmula da deformação específica..................................p. 51

Fórmula 4.2 - Fórmula da Teoria do Intervalo de Confiança.....................p. 56

Fórmula 6.1 - Fórmula do momento de força..........................................p. 66 


\section{LISTA DE ABREVIATURAS}

- PdAg - Paládio-Prata

- $\mu \varepsilon-$ micro strain 


\section{RESUMO}

O sucesso dos implantes osseointegrados tem a influência decisiva dos aspectos biomecânicos, os quais interagem implantes, tecido ósseo e as próteses. O equilíbrio das forças que atuam sobre este complexo, remete-nos às diversas técnicas e materiais utilizados para a confecção das próteses fixas implanto-suportadas. O desenvolvimento de técnicas e materiais, bem como os desenhos das próteses vem trazendo um novo alento nas pesquisas. Este trabalho teve como objetivo averiguar a influência dos materiais de recobrimento estético, utilizados na confecção de próteses fixas implanto-suportadas, com relação à deformação destas próteses. Esta análise foi feita utilizando-se extensômetros lineares elétricos, analisando dois materiais de recobrimento. Um corpo de prova simulando uma prótese fixa de arco total, fundida em liga de paládioprata e recoberta em uma de suas metades por porcelana e na outra, por resina acrílica termopolimerizável. O corpo de prova foi fixado a um modelo-mestre e, após, aplicada uma carga estática vertical de 35,2 N, na extremidade livre, a uma distância de 10, 15 e $20 \mathrm{~mm}$ para distal do centro do implante terminal. Os resultados demonstraram que a aplicação de materiais de recobrimento estético, sobre uma infraestrutura metálica, tornam a mesma mais rígida e conseqüentemente com menor deformação. Outro fator confirmado nesta pesquisa foi a influência direta da extensão da extremidade livre que, nos pontos mais distantes de aplicação da carga, proporcionou maiores deformações. A pesquisa demonstrou que a porcelana proporciona menores índices de deformação da infra-estrutura metálica a ela associada, porém, fatores clínicos como qualidade e quantidade óssea, número e disposição dos implantes é que definem a escolha do material de recobrimento mais apropriado para cada situação. 


\section{INTRODUÇÃO}

A terapia com implantes osseointegrados teve, nas últimas quatro décadas, uma evolução significativa desde que foi primeiramente aplicada em humanos. A definição de osseointegração, como foi apresentada por Branemark, é um marco que separa o novo do velho na implantodontia. A publicação de inúmeros trabalhos por Branemark e colaboradores deu uma base científica e um senso de respeitabilidade necessários para a implantodontia ${ }^{38}$.

A avaliação da eficiência de implantes osseointegrados na reabilitação de inválidos orais totais e parciais comprovou esta evolução da implantodontia diante dos índices expressivos de sucesso, tanto na fase cirúrgica como na etapa protética. As complicações existentes são de natureza iatrogênica e não comprometem o sucesso desta modalidade restauradora ${ }^{43,44}$.

Grande ênfase foi dada ao processo de osseointegração e às etapas cirúrgicas, sendo necessário revisar os aspectos pertinentes à elaboração das próteses sobre implantes, não só visando uma melhor composição no aspecto biológico, estético e funcional, mas também a busca de técnicas e materiais que tornem sua utilização mais acessível sob o ponto de vista econômico, diminuindo os custos de confecção.

Por muitos anos, ligas metálicas nobres permaneceram como os materiais mais freqüentemente utilizados para a confecção das infra-estruturas das próteses sobre implantes. A utilização de ligas básicas não é corriqueira e a preocupação reside no potencial de corrosão entre metais diferentes ${ }^{38}$.

A possibilidade de se utilizar ligas alternativas teve seu despertar nas pesquisas realizadas na Universidade de Toronto, no Canadá ${ }^{43,44}$ com a introdução de ligas de paládio-prata, sendo posteriormente, desenvolvidos 
estudos com as ligas de cobalto-cromo na confecção da infra-estrutura para próteses fixas implanto-suportadas, as quais vêm apresentando resultados promissores.

As ligas de cobalto-cromo são mais rígidas e apresentam maior resistência à deformação que as ligas de paládio-prata permitindo a confecção de infra-estruturas com menor volume de metal, sem sacrificar a capacidade de absorção de forças, de grande valia em casos de espaço intra-oral limitado ${ }^{7}$. Além disso, a combinação favorável de biocompatibilidade, resistência à corrosão, fundibilidade, peso e baixo custo, corroboram para que as ligas de cobalto-cromo sejam confirmadas como uma alternativa às ligas nobres, como material de confecção das infra-estruturas de próteses fixas implantosuportadas $^{16}$.

Desde a introdução do conceito de osseointegração numa escala mundial, dada em 1982, um dos princípios básicos aplicados às restaurações sobre implantes era de que o implante deveria ser protegido do impacto da função oclusal ou parafunção. Esses princípios foram descritos por SKALAK, em 1983, em artigos clássicos e, posteriormente revisados por BRUNSKI (1995 e 1999). Evitar cerâmicas ou superfícies oclusais metálicas era um consenso universalmente aceito.

A necessidade de proteger o implante do trauma oclusal e o desejo de simular o efeito amortecedor do ligamento periodontal dos dentes naturais foram observados como bases para o desenho de um sistema de implante dental bem sucedido ${ }^{21,40}$. A percepção que a manutenção da osseointegração era dependente deste efeito amortecedor do material restaurador levou a complicações restauradoras freqüentes com próteses implanto-suportadas. 
A preocupação em obter uma associação entre materiais compatíveis sob o ponto de vista mecânico e biológico, a fim de promover uma correta distribuição do estresse durante a função, levou diversos autores ${ }^{3,4}$, 7, 8, 9, 10, 11, 13, 18, 19, 27, 29, 30, 35, 42 a estudarem os efeitos da combinação entre diferentes tipos de ligas metálicas e materiais de recobrimento oclusal. Destaque foi dado a próteses fixas implanto-suportadas com extremidade livre posterior, devido a sua complexidade biomecânica.

As próteses fixas implanto-suportadas com extremidade livre posterior, sofrem neste cantilever uma incidência de forças, gerando estresse mecânico sobre a infra-estrutura, implantes e osso de suporte. Este estresse que está diretamente relacionado a algumas variáveis como quantidade de carga, tipos de forças incidentes, distribuição e tamanho dos implantes e extensão do braço de cantilever levou a buscar materiais que promovessem um equilíbrio biomecânico. Infra-estruturas com maior rigidez associadas a materiais de cobertura oclusal que permitam a absorção e distribuição homogênea do estresse induzido garantem a longevidade da prótese e dos implantes.

A diversidade de materiais disponíveis no mercado, além da criteriosa avaliação da literatura científica pertinente, despertou o interesse na pesquisa de uma combinação, que senão ideal, venha a dirimir a gama de dúvidas relativas ao assunto.

A influência do material de recobrimento estético na deformação da infra-estrutura metálica e na transmissão do estresse ao conjunto próteseimplante-osso encorajou-nos a desenvolver este trabalho, o qual entendemos, ser de grande importância para elucidar sua aplicação prática na clínica diária. 


\section{REVISÃO DA LITERATURA}

$\mathrm{Na}$ busca de uma combinação ideal entre infra-estrutura e material de recobrimento são vastos os estudos visando conciliar a função e a estética. Desde a proposta inicial de Branemark ${ }^{5}$ para o protocolo de prótese fixa implanto-suportada até a entusiasmada introdução de ligas alternativas e as cerâmicas, muito se tem avaliado estes materiais no intuito de encontrar uma combinação onde tais características, estéticas e funcionais, sejam supridas.

A preocupação com a biomecânica, em especial com o estresse gerado durante a função mastigatória e a sua transmissão aos componentes do sistema infra-estrutura-pilar-implante tem despertado 0 interesse de pesquisadores para a investigação de materiais e técnicas de confecção desta modalidade de próteses fixas implanto-suportadas.

Em 1983, LEUNG; ZARB; PILLIAR ${ }^{23}$ ressaltaram a importância da infraestrutura no desempenho das próteses fixas implanto-suportadas, sendo que para isto a infra-estrutura deveria seguir parâmetros de confecção específicos, baseados no protocolo de próteses fixas preconizado por Branemark et al. ${ }^{5}$ Os autores sugerem neste estudo a utilização de ligas alternativas na confecção da infra-estrutura, baseados no alto custo das ligas áureas e à necessidade de manter a biocompatibilidade do sistema prótese-implante-tecido ósseo.

Foi investigada a obtenção de uma infra-estrutura com liga de paládioprata, menos cara e fundida diretamente sobre o cilindro de ouro. A avaliação da precisão de adaptação da infra-estrutura, sua capacidade de carga e o custo reduzido reforçaram as vantagens de se empregar tal método.

SKALAK ${ }^{33}$, em 1983, num trabalho pioneiro na avaliação dos aspectos biomecânicos das próteses fixas implanto-suportadas, analisou e discutiu a 
transmissão de estresse do sistema prótese e implantes osseointegrados ao tecido ósseo. Dentre as conclusões do autor destacam-se:

A dependência direta do número, arranjo, resistência dos implantes e forma de resistência da própria restauração protética na distribuição de cargas verticais e oblíquas a que está sujeita uma prótese fixa implanto-suportada. Segundo o autor, uma prótese com estrutura mais rígida possibilitará a distribuição de estresse a diversos implantes mais efetivamente, enquanto que uma prótese com menor rigidez poderá ser utilizada quando a resistência desenvolvida em cada implante seja capaz de compensar a carga total que é aplicada sobre o conjunto prótese-implante.

Uma prótese fixa com conexão rígida aos implantes provê uma estrutura combinada, interagindo com o tecido ósseo e proporcionando uma maior resistência às forças incidentes sobre o sistema do que prótese ou tecido ósseo agindo individualmente.

Como o implante apresenta uma justaposição ao tecido ósseo a transmissão de estresse gerado por forças estáticas ou dinâmicas será integral. Por isto, é importante a utilização de materiais com potencial de resiliência para que absorvam e distribuam, de forma mais efetiva as cargas, como a resina acrílica dos dentes artificiais.

Baseados nos estudos de WORTHINGTON; BOLENDER; TAYLOR ${ }^{38}$ em 1987, DAVIS; ZARB; $\mathrm{CHAO}^{10}$, em 1988, utilizando a análise do elemento finito e strain gauges para a verificação de dados, realizaram um experimento onde avaliaram o deslocamento e a distribuição de estresse em uma infraestrutura de prótese fixa implanto-suportada, sob carga determinada. O número de pilares variava de cinco até dois. 
A infra-estrutura foi fundida em liga de paládio-prata, diretamente sobre os cilindros de ouro e, posteriormente parafusada aos pilares com os parafusos destes cilindros. Uma carga estática vertical de $20 \mathrm{~kg}$ era aplicada a uma distância de $10 \mathrm{~mm}$ para distal do pilar terminal e, realizada a análise do elemento finito. Um strain gauge foi fixado na superfície superior do braço de cantilever da infra-estrutura, a uma distância de $7 \mathrm{~mm}$ para distal do pilar terminal e uma carga de $20 \mathrm{~kg}$ foi aplicada a $14 \mathrm{~mm}$ deste pilar terminal. A análise do elemento finito revelou que a maior deflexão da infra-estrutura ocorreu quando o número de pilares foi alterado de três para dois.

A distribuição do estresse foi muito similar quando se utilizavam quatro ou cinco pilares. A mensuração da deflexão através de strain gauges demonstrou que quanto menor a quantidade de pilares utilizados, maior a deflexão do cantilever, chegando a tocar na base do modelo quando utilizados dois pilares.

Ainda embasados nesta observação, os autores citam ser maior o tempo necessário para que valores de tensão semelhantes fossem atingidos. Este estudo enfatiza a necessidade de estudos adicionais para determinar os efeitos de impacto e de cargas cíclicas, os quais podem, em longo prazo, gerar danos maiores para o sistema prótese-fixação-osso de suporte.

No mesmo ano, $\mathrm{CHAO}$ et al. ${ }^{7}$, investigaram a possibilidade de se utilizar ligas de cobalto-cromo para a confecção de infra-estruturas de próteses fixas implanto-suportadas. Para a realização deste estudo, um modelo mestre de liga de alumínio contendo réplicas de intermediários convencionais, foi preconizado.

Foram idealizadas infra-estruturas em cobalto-cromo e prata-paládio, até então largamente utilizadas. As infra-estruturas de cobalto-cromo tinham como características uma extensão em cantilever de $22 \mathrm{~mm}, 2,5 \mathrm{~mm}$ de largura 
e $4 \mathrm{~mm}$ de espessura. Para as ligas de paládio-prata a infra-estrutura apresentava valores de cantilever e espessura igual, variando a largura que era superior, isto é, de $6 \mathrm{~mm}$.

A precisão de adaptação da infra-estrutura aos intermediários foi analisada através de um microscópio de luz visível e a tensão gerada na superfície dos cantilevers pela utilização de extensômetros (strain gauges) e análise da fotoelasticidade. Os extensômetros foram fixados no braço do cantilever a uma distância de 7, 10 e 14 mm para distal do intermediário terminal.

As infra-estruturas eram parafusadas no modelo mestre e aplicada uma carga vertical de $20 \mathrm{~kg}$ no braço de cantilever, a distâncias de 14 e 20 mm para distal do intermediário terminal. A carga era aplicada com uma máquina de ensaio universal (Instron Universal Testing Machine), a uma velocidade de 0,1 $\mathrm{mm} / \mathrm{min}$. Os dados obtidos entre as duas ligas metálicas foram comparados, e os resultados com as ligas de cobalto-cromo são entusiasmantes.

Com relação à passividade de assentamento, as infra-estruturas assentaram passivamente aos intermediários, sendo necessários pequenos ajustes para as estruturas de cobalto-cromo. A média de desajuste marginal, entre infra-estrutura e intermediário foi de $26,4 \mu \mathrm{m}$ e $8 \mu \mathrm{m}$, respectivamente para as ligas de cobalto-cromo e prata-paládio.

Em termos de adaptação, as ligas de paládio-prata apresentaram maior precisão que as ligas de cobalto-cromo. Os autores também observaram que a tensão gerada no cantilever era menor, quanto mais próximo do intermediário terminal fosse aplicada à força e, independente do local de aplicação da força, se a 14 ou $20 \mathrm{~mm}$ de distância do intermediário terminal, a tensão gerada sempre se situava mais próxima deste intermediário. 
As ligas de cobalto-cromo apresentam como característica principal a maior dureza, em relação às ligas de paládio-prata, conferindo-lhes maior capacidade de carga e com isto possibilitando a confecção de infra-estruturas menos volumosas, mais delicadas e resistentes. Estas particularidades são uma grande vantagem em casos de espaço intra-oral limitado, preservando assim as características mecânicas desta infra-estrutura.

DAVIS et al. ${ }^{11}$, em 1988, estudando as armações de próteses fixas implanto-suportadas adicionaram materiais estéticos e analisaram os efeitos destes materiais na formação da superestrutura oclusal. Os autores se utilizaram infra-estruturas suportadas por cinco implantes sobre as quais foram adicionadas camadas de resina acrílica e porcelana.

Uma camada de 8 a $10 \mathrm{~mm}$ de amplitude destes materiais foi aplicada sobre as infra-estruturas $e$, posteriormente, os corpos de prova foram submetidos a uma carga vertical estática de $20 \mathrm{~kg}, 10 \mathrm{~mm}$ distal ao implante terminal. Utilizando a análise do elemento finito tridimensional foram avaliadas a distribuição de estresse, deflexão na armação e parafuso do coping. Uma condição transiente foi desenvolvida para situações de impacto baixo, simulando uma velocidade de $800 \mathrm{~cm} / \mathrm{min}$, que é uma velocidade estimada como limite extremo de velocidade mandibular durante a mastigação.

$\mathrm{Na}$ coleta dos resultados, a utilização de porcelana, sob uma carga estática, sobre a infra-estrutura resultará em menor deflexão do braço de extremo livre, menos estresse para a infra-estrutura e parafuso do coping e uma maior absorção de estresse pela superestrutura. Isto, porque a porcelana apresenta módulo de elasticidade maior que a resina acrílica.

Já, na condição de impacto, ocorreu uma alteração dos benefícios da porcelana em relação à resina acrílica. A resina acrílica absorveu mais o 
impacto do que a porcelana, transferindo menos estresse para a infra-estrutura e parafuso do coping. Por ser mais resiliente, a resina acrílica não transfere muito estresse para a infra-estrutura, permanecendo os efeitos localizados.

A conclusão dos autores é de que enquanto a resina é benéfica em situações dinâmicas de impacto, a porcelana é superior sob cargas estáticas.

Preocupado em avaliar os aspectos biomecânicos que envolvem materiais, desenho das infra-estruturas e forças incidentes sobre o complexo restaurador, BRUNSKI et al. ${ }^{6}$, em 1988, salientaram a escala de forças axiais incidentes sobre a dentição natural, que varia de 200 a $2440 \mathrm{~N}$, e as forças oblíquas que se situam na faixa de $30 \mathrm{~N}$.

Para próteses fixas implanto-suportadas forças de 42 até $412 \mathrm{~N}$ foram observadas em trabalhos realizados na Suécia. Segundo os autores ainda não existem estudos "in vivo" que meçam os componentes de carga sobre implantes dentais. Porém, estas cargas são importantes para a análise da interação entre desenho, material e tecidos de suporte. Por isto, forças "in vivo" devem ser estimadas, e as estimativas utilizadas para análise do estresse gerado sobre implante e/ou estruturas circunjacentes.

O estudo de RANGERT; JEMT; JÖRNEUS ${ }^{27}$, em 1989, salientou a importância do desenho das próteses e o posicionamento dos implantes sobre o estresse gerado no tecido ósseo e nos próprios componentes do sistema de implante-prótese. Os autores discutiram os parâmetros biomecânicos que regem as cargas aplicadas sobre os implantes, sugerindo princípios a serem observados para que os problemas decorrentes sejam minimizados.

Os implantes estão sujeitos a dois tipos principais de forças que devem ser consideradas: forças axiais e momento de torção. A força axial é favorável à 
medida que promove uma distribuição mais uniforme do estresse através do implante, enquanto que o momento de torção promove estresse sobre 0 implante e tecido ósseo de suporte.

As próteses fixas totais mandibulares, sustentadas por implantes situados na região anterior e com cantilever na região posterior se assemelham a sistemas de alavancas de classe I. Os implantes mais posteriores de cada lado da prótese representam o fulcro da alavanca.

Deste modo os implantes anteriores ao último absorverão uma força de tensão proporcional ao braço de alavanca. Já os implantes terminais, que funcionam como fulcro, sofrerão forças de compressão, que correspondem à soma da força oclusal aplicada à força de tensão compensadora.

Quando dois ou mais implantes dividem entre si a carga advinda do cantilever, a análise torna-se mais complexa. Porém, o comprimento do cantilever continua sendo o parâmetro crucial em relação à distância entre os implantes mais anterior e mais posterior. A distribuição das fixações através da curvatura da linha oclusal, seguindo um arranjo curvo, aumenta a margem de segurança.

O implante isolado constitui um sistema de forças de compensação e um braço de alavanca. A analogia com a alavanca de classe I também se aplica a este caso, porém o braço de alavanca compensatório resume-se ao raio do elemento intermediário e não da distância entre implantes. O que pode ocorrer é a separação do conjunto intermediário/cilindro de ouro, quando sob carga, à medida que os parafusos absorvem a força de tensão total. Neste caso a borda posterior do intermediário age como fulcro e o momento de torção sobre o implante induz uma força interna extremamente alta na união parafusada, podendo facilmente sobrecarregar os parafusos. 
Momentos de torção também são induzidos por forças transversais. $O$ braço de alavanca estará localizado na distância entre o contato oclusal e a união do intermediário com o implante, pois a junção entre o parafuso de ouro e o parafuso do intermediário forma um conjunto único quando parafusados juntos. Fraturas são esperadas no parafuso de ouro, sendo este o ponto mais vulnerável do sistema. A causa mais comum de fratura de um parafuso é o seu afrouxamento. Persistindo a fratura, mesmo com a troca e um correto aperto do parafuso, pode estar ocorrendo falta de precisão na adaptação.

Havendo um aperto adequado e precisão de adaptação e mesmo assim a fratura ocorrer, o sistema provavelmente estará sobrecarregado. Neste caso a reavaliação da extensão do cantilever, o esquema oclusal e o posicionamento dos implantes deve ser feita.

A extensão do cantilever deve ser considerada em relação aos aspectos mecânicos e biológicos avaliando-se quatro itens:

a. Qualidade do osso: pode ser o fator mais importante na determinação da extensão posterior de cantilever, permitindo em média extensões de 15 a 20 $\mathrm{mm}$, no osso mandibular.

b. O arranjo ou distribuição dos implantes, se linear ou curvo: recomenda-se um extremo livre mais curto para arranjos lineares e, no mínimo 10 mm de distância interfixações no sentido antero-posterior.

c. Força de mastigação e tipo de arco antagonista: o tipo de paciente e hábitos orais ou parafuncionais devem ser considerados. 
d. O número e tamanho dos implantes colocados, que não somente afetam o suporte das próteses, mas que indiretamente refletem a quantidade óssea disponível para suportar o estresse gerado pela prótese.

Em 1989, FALK et al. ${ }^{12}$,estudaram o padrão de força oclusal em dentições restauradas com próteses fixas implanto-suportadas mandibulares ocluindo contra próteses totais maxilares. Os autores utilizaram extensômetros lineares elétricos para o registro dos contatos oclusais.

Os resultados obtidos com oito contatos oclusais distribuídos demonstraram que $70 \%$ das forças de fechamento total e forças de mastigação foram dirigidas ao segmento de extremo livre e apenas 30\% ao segmento anterior suportado pelos implantes.

Em estudos recentes com quatro contatos oclusais somente, foram encontrados índices de 55 e 45\%, respectivamente, para as mesmas localizações. Esses resultados indicam que fatores como o desenho oclusal e número e distribuição dos contatos oclusais são importantes para a distribuição de força e estresse sobre a prótese fixa implanto-suportada.

Os autores também sugerem que um grande número de contatos oclusais não é necessariamente preferível em casos de próteses fixas implantosuportadas com extremo livre extenso. Ainda sugerem investigações posteriores a respeito do assunto.

ISMAIL et al. ${ }^{18}$, em 1989, questionando a indicação de resinas acrílicas como material de recobrimento oclusal em próteses implanto-suportadas avaliaram, através da análise do elemento finito tridimensional, o estresse gerado utilizando-se diversos tipos de materiais de recobrimento. 
Os autores utilizaram resina acrílica, resina composta, porcelana, liga de ouro e ligas metálicas não nobres neste estudo. Cargas oclusais específicas foram aplicadas e os valores de estresse em cada material foram calculados. Os resultados demonstraram não haver diferença entre os valores e padrões de estresse nas próteses fixas implanto-suportadas e o tecido ósseo de suporte.

Os autores salientam que a utilização de dentes de resina como um absorvedor de choque pode não ser válido, e que o critério estético e funcional devem ser usados para selecionar o material oclusal apropriado para cada situação.

WILLIAM et al. ${ }^{44}$, em 1990, desenvolveram um estudo utilizando-se da análise de elemento finito de estrutura bidimensional, onde os autores verificaram que as infra-estruturas de próteses fixas implanto-suportadas confeccionadas em ligas de cobalto-cromo, por apresentarem um alto módulo de elasticidade, em substituição às ligas de ouro, possibilitavam uma distribuição de carga mais uniforme ao longo desta infra-estrutura, produzindo menor estresse.

$\mathrm{GOLL}^{14}$, em 1991, num estudo onde abordava a produção de infraestruturas de próteses fixas implanto-suportadas, fundidas em bloco único e precisamente assentadas, teceu considerações clínicas e laboratoriais visando minimizar os erros mais freqüentes. Segundo o autor, alguns procedimentos executados com precisão e cuidados permitiriam o controle de etapas clínicas de modo a obter uma infra-estrutura fundida com adaptação precisa.

Recomenda, ainda, a utilização de componentes pré-fabricados em lugar dos componentes fundíveis, porque, de modo geral permitem uma melhor adaptação aos pilares 
O autor ressalta a importância de proteger os intermediários com capas para evitar o acúmulo de resíduos em sua superfície e indica, sempre que possível, fundir a infra-estrutura em peça única para que assim as propriedades físico-químicas do metal sejam mantidas.

Após a soldagem de duas ou mais partes da infra-estrutura, estas propriedades estariam alteradas e esta infra-estrutura não poderia ser tratada termicamente. Atenção também deve ser dada no momento do polimento da infra-estrutura, protegendo os cilindros de ouro com capas durante este procedimento e evitando desadaptações no assentamento desta estrutura.

SCHACKLETON et $\mathrm{al}^{32}$., em 1992, avaliando as principais complicações ocorridas nas próteses fixas implanto-suportadas, acompanhou um grupo de 28 pacientes, sendo 25 submetidos ao protocolo fixo preconizado por Branemark ${ }^{5}$. Após um acompanhamento de 10 a 70 meses, os autores verificaram que a maior incidência de problemas relacionados às falhas das próteses estavam direcionados à fratura de componentes protéticos ou da prótese em si.

As próteses fixas com extremo livre mais longo apresentaram uma gama de problemas mecânicos maior, em relação às de extremo livre mais curto.

Os resultados sugerem que a maior incidência de problemas protéticos estão relacionados ao estresse gerado na prótese e, que o comprimento dos extremos livres devem ser limitado a $15 \mathrm{~mm}$, para que assim menos estresse seja colocado sobre a infra-estrutura e sejam minimizados os problemas mecânicos.

O material de recobrimento oclusal foi abordado por HOBKIRK ; PSSAROS $^{17}$, em 1992, onde os autores realizaram um estudo para avaliar a 
influência do material de recobrimento oclusal no pico de força mastigatória em prótese fixas implanto-suportadas. Os autores utilizaram um transferidor de força eletrônica de três canais acoplados a próteses fixos implanto-suportadas com superfícies oclusais em resina acrílica e porcelana, com articulação balanceada, em cinco indivíduos, para que fossem avaliadas as forças mastigatórias enquanto estes indivíduos mastigavam alimentos de diferentes consistências.

Os autores não puderam observar diferenças nos valores de carga quando usados dentes de resina acrílica ou de porcelana. Os picos médios de força mastigatória variaram consideravelmente de indivíduo para indivíduo. Diferentes picos médios de força mastigatória foram observados com diferentes tipos de alimentos.

Porém, diversos fatores, como velocidade de mastigação e variação de consistência dos alimentos da amostra, além da particularidade nos movimentos mastigatórios dos indivíduos analisados colaboraram para que estes resultados não demonstrassem diferenças significativas entre os dois materiais utilizados no estudo.

Em 1992, CIBIRKA et al. ${ }^{8}$ apresentaram um estudo "in vitro" do efeito amortecedor do material restaurador oclusal de próteses fixas implantosuportadas. Neste estudo os autores colocaram um implante tipo Branemark numa mandíbula de cadáver humano entre a sínfise e forame mentoniano.

Um extensômetro linear elétrico, fixado na placa óssea cortical da mandíbula, foi utilizado para medir a força aplicada por uma máquina de ensaio INSTRON sobre superfícies oclusais em ouro, resina acrílica e porcelana. Uma fração de alimento era interposta entre a superfície a ser testada e a ponta da máquina de ensaio, a qual seria clivada sob uma força quantificada. 
A força aplicada era captada pelo extensômetro para que fosse calculado o quociente de absorção da força. Os resultados não demonstraram nenhuma diferença estatisticamente significante do quociente de força de absorção entre as superfícies de ouro, resina e porcelana. Porém, os autores admitem que fatores como a ausência de osseointegração, pode ter desenvolvido um resultado não condizente com a realidade "in vivo".

HULTERSTRÖM ${ }^{16}$, em 1994, estudando as ligas alternativas usadas na confecção de infra-estruturas de prótese fixa implanto-suportada, avaliou a utilização de ligas de cobalto-cromo. Foram tratados 66 pacientes, na Clínica de Prótese do Serviço Público de Uppsala, Suécia, por meio de próteses fixas implanto-suportadas. Para tal foram utilizados 333 implantes do tipo Branemark sobre os quais foram confeccionadas 67 próteses fixas.

As estruturas das próteses foram elaboradas por diferentes técnicas, porém com ligas de cobalto-cromo. As técnicas utilizadas foram a união mecânica do cilindro de ouro com resina acrílica, a combinação de soldagem parcial e resina acrílica e a soldagem total do cilindro.

Reações teciduais adversas não foram observadas. O autor verificou que as estruturas confeccionadas em ligas de cobalto-cromo oferecem muitas vantagens como o baixo custo, em relação às ligas áureas, boa biocompatibilidade, resistência à corrosão, facilidade de fundição, baixo peso e boa dureza. Estas características levaram-no a concluir como encorajadora a idéia de confeccionar infra-estruturas metálicas de próteses fixas implantosuportadas com ligas de cobalto-cromo.

Com o intuito de avaliar a influência do comprimento da extremidade livre em próteses fixas implanto-suportadas na perda óssea marginal e 
transmissão de estresse para a mandíbula, WHITE; CAPUTO; ANDERKVIST ${ }^{43}$, em 1994, utilizaram a análise de fotoelasticidade. Um modelo representando uma mandíbula humana, com reabsorção moderada, foi confeccionada com material fotoelástico. Cinco implantes do sistema Branemark (Nobelpharma), com $13 \mathrm{~mm}$ de comprimento, foram instalados entre os forames mentonianos, sendo que os implantes do lado esquerdo foram dispostos ligeiramente mais próximos que os do lado direito.

No plano sagital, os implantes do lado direito foram instalados perpendicularmente ao plano oclusal, enquanto que os do lado esquerdo estavam com uma inclinação de $5^{\circ}$ para distal. A infra-estrutura foi fundida com uma liga de Pd-Cu-Ga-In-Au e sobre esta, aplicada uma camada de resina acrílica de superfície plana permitindo a aplicação de forças oclusais perpendiculares.

A infra-estrutura apresentava uma extensão máxima de $30 \mathrm{~mm}$ na região posterior aos implantes distais e $15 \mathrm{~mm}$ na região anterior aos mesmos. A aplicação de carga foi a cada $5 \mathrm{~mm}$, sendo aplicada uma força de $89 \mathrm{~N}$ na região posterior, até $30 \mathrm{~mm}$ e uma força de $134 \mathrm{~N}$ nos mesmos pontos, porém, até $20 \mathrm{~mm}$ em ambos os lados.

Esta força de $134 \mathrm{~N}$ também foi aplicada aos pontos localizados na região anterior. Independente do comprimento do cantilever, os autores puderam observar que os maiores níveis de estresse concentraram-se na crista alveolar distal adjacente ao implante terminal, no lado de aplicação da carga. Pequenos níveis de estresse foram observados na região apical destes implantes.

Quando as forças foram aplicadas na região anterior o estresse localizou-se no implante mais próximo do ponto de aplicação da força. As 
pequenas variações de inclinação dos implantes apresentaram efeitos distintos, sendo a maior concentração de estresse no implante terminal esquerdo mais inclinado para distal em relação ao direito mais verticalmente posicionado.

A falta de ancoragem para o posicionamento de um número ou mesmo localização adequada dos implantes tornou necessária a utilização de próteses fixas com extensões livres ou cantilevers.

Analisando este fato, em 1995, VAN ZYL et al. ${ }^{41}$, através da análise do elemento finito tridimensional, estudaram a distribuição de estresse no tecido ósseo que circunda os implantes, em casos em que estes suportavam próteses fixas com extremo livre bilateral. Os autores aplicaram uma força vertical estática de $100 \mathrm{~N}$ ao longo de toda a extensão dos cantilevers, a partir de $7 \mathrm{~mm}$ do implante terminal, num intervalo de $2 \mathrm{~mm}$ até $25 \mathrm{~mm}$ de distância do mesmo implante.

Os resultados deste estudo demonstraram que áreas de estresse menor foram observadas nas regiões mesial e distal dos implantes, enquanto que valores maiores foram observados nas regiões vestibular e lingual. Em relação à extensão do cantilever, dentre as mensurações realizadas, o comprimento de $15 \mathrm{~mm}$ demonstrou ser uma distância limite ideal para a mesma.

Os autores concluíram que cantilevers com extensão maior que $15 \mathrm{~mm}$ podem gerar estresse nas regiões vestibular e lingual dos implantes a ponto de colocar em risco a sua integridade.

SPIEKERMANN ${ }^{35}$, em 1995, citou como meios eficazes de análise dos aspectos biomecânicos incidentes nas próteses implanto-suportadas, os seguintes métodos: 
Análise do elemento finito: permite o cálculo da distribuição e concentração de estresse e deformações no sistema prótese-implante-tecido ósseo, através de estruturas bi ou tridimensionais computadorizadas em forma de grade, porém a descrição matemática da interface é problemática.

Análise da Birrefringência: a técnica utiliza luz monocromática polarizada e é realizada através de cargas aplicadas em implantes ancorados em modelos plásticos. Fenômenos de sobreposição são observados, devido aos mesmos serem muito largos em relação à espessura necessária para o procedimento, tornando este método pouco aplicável atualmente.

Mensuração de cargas "In vivo" e "In vitro": esta técnica proporciona dados mais precisos a respeito das forças incidentes sobre dentes e implantes e sua transferência às estruturas de suporte. Experimentos "in vivo" se tornam menos comuns devido à dificuldade de acomodação do aparato apropriado na cavidade oral, tanto do ponto de vista técnico como biológico, porém, os trabalhos "in vitro" fornecem dados valiosos.

Estudos da resistência de união entre implante e tecido ósseo: realizados através de testes de cisalhamento, tração e compressão, os resultados destes estudos sofrem influências significativas das condições experimentais. Exige uma avaliação crítica dos dados obtidos a partir de casos individuais.

MILLINGTON et al. ${ }^{25}$, em 1995, realizaram um estudo relacionando o estresse gerado na infra-estrutura de próteses implanto-suportadas e o tamanho da discrepância de assentamento destas aos pilares.

Para este estudo foi utilizado um modelo laboratorial com quatro implantes dispostos linearmente sobre os quais foram parafusadas infraestruturas, com uma camada fotoelástica no seu topo, e que posteriormente 
receberam um torque de $10 \mathrm{Ncm}$ para a fixação. Após a constatação do assentamento passivo proposto por $\mathrm{JEMT}^{21}$, no primeiro pilar, foram criadas discrepâncias, colocando-se pontos de metal nos três pilares remanescentes.

Para monitorar o gap gerado foi adaptado ao topo da infra-estrutura um transferidor de deslocamento variado linear, antes e após a introdução do fator de desadaptação. Para avaliar o estresse gerado na infra-estrutura foi utilizado um polariscópio de reflexão, com um compensador de balanceio nulo, conectado a um microprocessador.

A análise dos resultados obtidos demonstrou que a ocorrência de discrepâncias gerou estresse maior nos pilares terminais que nos intermediários e também, que o nível de estresse estático causado pela desadaptação da infra-estrutura é dependente do tamanho, forma e localização dos gaps; distância entre os pilares e forma, dimensões e dureza do metal das infraestruturas.

Conseqüentemente, o autor concluiu que existe uma relação positiva entre o tamanho da desadaptação e o estresse gerado na infra-estrutura das próteses implanto-suportadas.

Avaliando, num estudo piloto "in vitro", a distribuição de carga nas próteses fixas implanto-suportadas com infra-estrutura de extremo livre, WANG; HOBKIRK, em 1996, utilizaram extensômetros lineares elétricos.

Trabalhando com uma mandíbula artificial e variando a combinação de localização dos implantes, comprimento do extremo livre, distância entre implantes e magnitude de carga, os autores verificaram a influência destas variáveis. 
Os resultados mostraram que a força maior recaía sobre os dois implantes terminais; que a magnitude de força era proporcional ao comprimento do extremo livre e que variáveis como combinação dos implantes, espaçamento entre os implantes e a localização dos implantes tinham influência na variação da magnitude de cargas sobre os implantes.

Em 1996, ASSIF et al. $^{3}$, utilizando strain gages e análise de fotoelasticidade, analisaram a transmissão de forças e a distribuição de estresse nos vários elementos que compõem um sistema de prótese fixa implanto-suportada, como implantes, estruturas de suporte e a prótese fixa de extremo livre bilateral, quando submetidos a uma carga.

Os autores confeccionaram um modelo fotoelástico contendo cinco réplicas de implantes e seus respectivos intermediários, sobre os quais foi encerada e fundida, com uma liga de prata-páladio (Palliag M, Degussa Dental), uma infra-estrutura com extremos livres bilaterais. Os extensômetros lineares elétricos foram fixados na superfície superior da infra-estrutura, entre cada intermediário e, logo após o implante terminal, num total de 06 sensores. Um sétimo strain gage foi fixado no intermediário 4 , sendo que a numeração era de 1 a 5 no sentido horário. Em seguida, foi aplicada uma carga estática axial, em 7 pontos: na extremidade distal do cantilever e sobre a cabeça do parafuso de fixação em cada implante.

Os resultados demonstraram que os maiores níveis de distorção foram observados nos strain gages localizados próximos ao cantilever, ou seja, na distal do implante terminal, quando a carga era aplicada no final da extremidade livre.

Os autores concluíram que há uma relação direta entre a rigidez do material da infra-estrutura metálica e o modo de distribuição do estresse na 
própria infra-estrutura e nas estruturas de suporte dos implantes, quando submetidas a uma determinada carga. Ainda que o modo de transferência da carga e a distribuição do estresse foi diretamente proporcional à distância dos componentes do complexo restaurador ao ponto de aplicação da carga, para cada carga dada.

Em 1996, PAPAVASILIOU et al. ${ }^{26}$, realizaram um estudo do estresse gerado na região periférica do implante dental. Para este estudo os autores utilizaram a análise do elemento finito tridimensional, levando em consideração alguns pontos como tipos de mandíbulas edêntulas, materiais veneer, ausência da cortical óssea, elementos intramóveis, direções de aplicação das cargas e níveis de carga.

Os autores observaram que fatores como a ausência da cortical óssea, direção das cargas aplicadas tiveram influência direta no aumento do estresse gerado ao redor do implante, porém o tipo de material venner utilizado no recobrimento destas próteses não influenciou diretamente nos valores de estresse gerado.

SERTGÖZ; GÜVENER ${ }^{31}$, em 1996, avaliaram a distribuição de estresse na interface, implante/tecido ósseo, utilizando a análise de elemento finito tridimensional, num modelo de simulação de prótese fixa, suportada por seis implantes, fixados num modelo de osso mandibular (cortical e esponjoso) e com cantilevers posteriores bilaterais.

Para este estudo foram utilizados três diferentes comprimentos de implantes $(7,15$ e $20 \mathrm{~mm})$ e cantilevers $(7,14,28 \mathrm{~mm})$, totalizando nove modelos. Uma força de $75 \mathrm{~N}$ era aplicada perpendicularmente à infra-estrutura, na porção central e na região correspondente ao elemento mais posterior do cantilever. 
As análises de distribuição de estresse máximo revelaram que estes se concentravam na interface osso/implante no implante mais distal, no lado de aplicação da carga. Quando a carga era aplicada verticalmente o estresse de tração se concentrava no tecido ósseo nas regiões mesial e distal dos implantes, enquanto que ao sofrer uma carga horizontal este estresse era evidente nas regiões lingual e vestibular. Aumentando a extensão do cantilever houve um aumento nos valores de estresse na interface osso/implante no implante terminal. A variação no comprimento dos implantes não teve influência significativa na distribuição de estresse nesta interface.

Posteriormente, em 1997,SERTGÖZ; GÜVENER realizaram um estudo com modelo finito tridimensional, analisando a distribuição do estresse na interface osso/implante, variando o comprimento dos implantes e do extremo livre. Os autores comprovaram as observações anteriores de SKALAK ${ }^{33}$, RANGERT ${ }^{27}$ e ADELL et al. ${ }^{1}$ que quanto maior o comprimento do extremo livre maior o estresse gerado, principalmente sobre o implante terminal. No entanto não observaram alterações estatisticamente significantes associadas com 0 comprimento dos implantes.

No intuito de avaliar a melhor combinação de materiais para a construção de próteses implanto-suportadas, SERTGÖZ ${ }^{30}$, em 1997 , desenvolveu um estudo utilizando-se da análise tridimensional do elemento finito.

O autor simulou uma típica prótese fixa total no arco mandibular, suportada por 6 implantes localizados na região intermentoniana e com extensões em cantilever bilaterais de $16 \mathrm{~mm}$. O objetivo deste estudo era o de 
determinar a melhor combinação de materiais para a confecção da restauração protética.

Foram avaliados como material de recobrimento oclusal a resina acrílica, resina composta, porcelana e ligas de ouro, paládio-prata, cobaltocromo e titânio como materiais para a infra-estrutura. Ao modelo de elemento finito foi aplicada uma carga de $172 \mathrm{~N}$, que correspondia à média de força durante a mastigação em uma prótese fixa implanto-suportada com duas unidades em cantilever posterior bilaterais, ocluindo contra uma prótese total.

A força foi aplicada no centro dos implantes terminais, no final dos cantilevers e em quatro pontos distribuídos na região anterior, entre os centros dos implantes mais distais. Os resultados mostraram ser o estresse máximo gerado, bem inferior aos limites de tração e compressão do osso cortical e medular.

O uso de materiais mais resilientes para a confecção da infra-estrutura não alterou significativamente o prognóstico biológico das próteses fixas implanto-suportadas, não gerando efeitos deletérios ao tecido ósseo. Por outro lado, materiais mais rígidos usados na confecção das infra-estruturas das próteses fixas implanto-suportadas, mecanicamente, diminuíram o estresse gerado nos parafusos de ouro.

Assim o autor deduziu que, a alta resistência à torção da infraestrutura reduziu o risco de sobrecarga mecânica nos parafusos de retenção, principalmente em estruturas com extensões em cantilever. Isto sugere que a utilização de materiais mais rígidos ajuda a prevenir falhas protéticas. 
Do ponto de vista biomecânico, a melhor combinação de materiais encontrada neste estudo foi a infra-estrutura confeccionada em liga de cobaltocromo, com superfície oclusal em porcelana.

STEGARIOU et al. ${ }^{36}$, em 1998, avaliaram, através da análise do elemento finito tridimensional, a distribuição de estresse no osso, implante e abutment (pilares) quando liga de ouro, porcelana e resina foram usadas para a confecção de uma prótese fixa implanto-suportada de três elementos. Uma força foi aplicada axialmente e obliquamente no centro do pôntico.

Para a liga de ouro e porcelana o estresse equivalente máximo encontrado foi similar em cada parte dos modelos. Em quase todos os casos, o estresse equivalente máximo encontrado nos modelos de resina foi similar ou maior do que aquele encontrado com liga de ouro e porcelana.

Os maiores valores de estresse foram encontrados com as resinas no abutment (pilar) do implante sob carga axial. Os autores também observaram que os valores de estresse mais elevados foram observados quando era aplicada uma carga oblíqua.

A conclusão dos autores foi de que o estresse equivalente máximo encontrado no osso, implante e pilar foi semelhante utilizando liga de ouro e porcelana. Ainda, considerando a predominância de cargas axiais intraoralmente, o uso de resina composta ou acrílica ao invés de porcelana ou ouro, pode aumentar o estresse no implante e no pilar na ausência de uma infra-estrutura de metal.

RUBO et al. ${ }^{28}$, em 1999, verificaram a distribuição de estresse entre os implantes que suportavam uma prótese fixa implanto-suportada com extremo livre bilateral. Para este estudo os autores utilizaram a análise do elemento 
finito tridimensional e incluíram algumas variáveis como: densidade do osso trabecular, comprimento dos intermediários e implantes, extensão do cantilever, número e arranjo dos implantes, grau de curvatura da mandíbula, e liga usada na confecção da infra-estrutura (prata-paládio ou cobalto-cromo).

Uma carga de $100 \mathrm{~N}$ foi aplicada sobre o modelo para simular a força oclusal. Houve uma tendência do estresse ser melhor distribuído quando utilizado o arranjo curvo, com uma pequena extensão de cantilever, implantes longos e infra-estrutura mais rígida. A densidade do osso trabecular parece não ter influenciado na distribuição do estresse.

Porém, a diminuição do número de implantes gerou um estresse maior sobre os intermediários remanescentes. A distribuição do estresse sobre a infra-estrutura foi independente da curvatura da mandíbula, porém foi menor quando os implantes e intermediários eram mais longos e a liga utilizada para confecção da infra-estrutura, mais rígida.

Em 1999, TOM et al. ${ }^{39}$ teceram considerações sobre a forma de secção transversal ideal para as infra-estruturas de próteses fixas implanto-suportadas para que estas pudessem suportar o estresse gerado durante a função mastigatória. Utilizando a análise do elemento finito tridimensional simplificado, os autores montaram uma prótese fixa mandibular sobre 5 implantes. A prótese fixa era composta de metal e recoberta por resina acrílica. Foram avaliados seis tipos de secção transversal, para as estruturas metálicas, observando o estresse gerado nos pilares durante a aplicação de cargas de torção durante a mordida bilateral posterior.

Os autores concluíram que a forma de secção transversal da infraestrutura das próteses fixas implanto-suportadas tem influência significante na distribuição de estresse nos pilares e implantes. Observaram que a forma 
retangular vertical parece ser a forma que menos gera estresse aos pilares e, que a utilização de material com módulo elástico maior não necessariamente leva a um aumento no estresse nos pilares existentes.

O efeito absorvedor de impactos, de cinco materiais utilizados nas próteses fixas implanto-suportadas, foi analisado por GRACIS et al. ${ }^{13}$, em 1999. Os autores avaliaram o efeito amortecedor de materiais como liga de ouro, liga de metal nobre para porcelana, porcelana, uma resina micro-particulada fotoativada e processada em laboratório e uma resina acrílica polimerizada com pressão.

Corpos de prova foram confeccionados com os diferentes tipos de materiais e submetidos a testes de aplicação de carga, sendo anotados os dados relativos à força aplicada e ao tempo para que fosse atingido o pico de força.

Os dados foram anotados por um osciloscópio digitador e aplicados testes estatísticos. Os resultados demonstraram que as resinas reduzem em até $50 \%$ as forças de impacto sobre as restaurações, o que biologicamente é um aspecto favorável. Porém, outras considerações com relação às propriedades físicas destes materiais devem ser consideradas antes de indicálos como substitutos para as porcelanas e ligas áureas como materiais de recobrimento oclusal das próteses implanto-suportadas.

Os autores ainda sugerem a avaliação de fatores como quantidade e qualidade de osso necessário para a absorção de impactos, além da análise do tipo de arco antagonista.

Em 2000, JACQUES ${ }^{20}$, realizou um trabalho cujo objetivo foi verificar a distribuição de estresse em componentes de prótese fixa implanto-suportada, 
através de strain gages, em função de duas ligas metálicas. Foram confeccionados corpos de prova simulando infra-estruturas de prótese fixa mandibular, em liga de paládio-prata e cobalto-cromo que foram posicionadas sobre um modelo mestre de alumínio.

Uma carga estática vertical de $100 \mathrm{~N}$ foi aplicada na extremidade livre, a uma distância de 10, 15 e $20 \mathrm{~mm}$ para distal do centro do intermediário terminal. Os resultados encontrados mostraram que em extensões grandes de cantilever, a liga de cobalto-cromo apresentou um padrão de distribuição de forças semelhante à liga de paládio-prata com cantilever curto.

Independente do local de aplicação da força e do tipo de liga utilizado na confecção das infra-estruturas, o intermediário mais próximo do ponto de aplicação da força foi o que registrou maior deformação específica. O emprego de uma liga mais rígida, no caso cobalto-cromo, na confecção de infraestruturas de prótese fixa implanto-suportadas permite braços em cantilever mais extensos.

No ano de 2000, HOLLWEG ${ }^{15}$, avaliou a passividade de adaptação de infra-estruturas para próteses implanto-suportadas, em função de dois tipos de ligas metálicas. Foram confeccionados corpos de prova simulando uma prótese fixa total mandibular em liga de cobalto-cromo e prata-paládio.

Estes corpos de prova foram posicionados sobre um modelo mestre e foram fixados strain gages na superfície mesial e distal de cada intermediário para detectar a deformação sofrida quando os parafusos de fixação eram apertados. Os resultados não foram estatisticamente diferentes entre si, sendo verificado um nível de passividade similar entre as infra-estruturas fundidas com liga de cobalto-cromo e prata-paládio. $\mathrm{O}$ autor sugere a utilização de ligas de 
cobalto-cromo na realização de pesquisas clínicas, visto que os resultados laboratoriais são promissores.

Visando avaliar o efeito amortecedor de vários materiais utilizados na confecção de próteses fixas implanto-suportadas, ÇIFTÇI; CANAY ${ }^{9}$, em 2000, utilizaram-se do método da análise do elemento finito tridimensional para o desenvolvimento de um estudo onde foram analisados cinco materiais: resina acrílica, resina composta, resina composta reforçada, liga de ouro e porcelana. Um software MARC/K7.2/Mentat 3.2 foi usado para analisar valores de estresse criados por forças horizontais e oblíquas.

Os autores observaram que, sob carga estática e condições de impacto, o uso de resina acrílica reduz o estresse que é transmitido à infraestrutura da prótese e à cortical óssea, característica que é devida ao seu baixo módulo de elasticidade, porém a sua baixa resistência à abrasão, absorção de água, descoloração e fratura são desvantagens do seu uso.

Os autores concluíram que materiais de resina são benéficos em reduzir o estresse tolerado sob diferentes condições de carga. Resina acrílica ou cerômeros (compósitos de resina modificados por vidro) reduziram o estresse de $25 \%$ a $15 \%$ respectivamente, quando comparado à espessura equivalente de porcelana ou metal.

JANSON $^{19}$, em 2000, utilizando-se de extensômetros lineares elétricos, avaliou a deformação sofrida pelas infra-estruturas de próteses fixas implantosuportadas com extremidade livre, confeccionadas em ligas de paládio-prata e cobalto-cromo, quando estas foram submetidas a uma carga estática de $100 \mathrm{~N}$ aplicada a 10, 15 e $20 \mathrm{~mm}$ de distância do implante terminal.

Foram colados extensômetros à distal do implante terminal nas superfícies inferior e superior da infra-estrutura. $O$ autor observou que infra- 
estruturas confeccionadas em liga de $\mathrm{CoCr}$ com extensão maior sofriam menor deformação que as confeccionadas com liga de PdAg, quando aplicada a força numa distância menor.

Baseado nestes dados o autor concluiu que as ligas de $\mathrm{CoCr}$ são excelente perspectiva na busca de uma combinação de materiais que visem aumentar o efeito amortecedor das infra-estruturas de próteses fixas implantosuportadas ou seja diminuir a carga sobre o implante e estruturas de suporte.

TAYLOR et al. $^{38}$, em 2000 fazendo uma revisão da literatura sobre as tendências correntes e perspectivas futuras das próteses sobre implantes ressaltou a preocupação de SKALAK ${ }^{33}$ em introduzir conceitos que permitissem restaurar implantes dentais protegendo-os da função e parafunção oclusal. Evitar cerâmicas ou mesmo superfícies oclusais metálicas era universalmente aceito.

Buscava-se o material restaurador que proporcionasse 0 efeito amortecedor do ligamento periodontal, por isto as resinas acrílicas, inicialmente foram eleitas como material restaurador ideal. Porém, com a utilização mais freqüente dos implantes dentais para a resolução de situações de edentulismo parcial ou mesmo de elementos unitários, onde o antagonista deixou de ser uma prótese total e passou a ser dentição natural, rapidamente mostrou-se ser inadequado o uso de resinas, principalmente, na parte posterior da boca.

A necessidade de freqüentes reparos convenceu muitos praticantes da implantodontia que o risco à osseointegração seria menor se os problemas de manutenção fossem reduzidos. A expectativa quanto à estética também corroborou para utilização de materiais mais naturais e estáveis como as cerâmicas. 
A introdução de novos componentes para a elaboração das restaurações cerâmicas facilitou a transição entre estes materiais. A preocupação em proteger os implantes dentais do impacto gerado pelas superfícies oclusais cerâmicas tem desaparecido da literatura. Segundo os autores o padrão de confecção de restaurações implanto-suportadas inclui, atualmente, o uso de materiais cerâmicos.

WISKOTT et al. ${ }^{45}$, em 2002, realizaram uma avaliação longitudinal do desgaste de três tipos de materiais veneer. Os autores avaliaram a cerâmica feldspática, como grupo controle, um compósito de matriz sintética com reforço mineral e uma resina acrílica. Foram desenvolvidas estruturas metálicas com liga de Au-Pt-Ag, sobre as quais foram aplicados os materiais de recobrimento oclusal, numa espessura média de 0,8 a $1 \mathrm{~mm}$. O experimento contou com 12 restaurações avaliadas num período de 24 meses, sendo perfiladas em 3, 6, 9, 12,18 e 24 meses.

O perfilamento das restaurações foi realizado utilizando um conector octogonal do sistema de implante ITI e a análise estatística através de software comercial.

Os autores concluíram que ao final do experimento os níveis de desgaste entre os três materiais foram semelhantes. Segundo estes autores, a taxa de desgaste das resinas é compatível com o seu uso clínico, porém, fatores como perda do brilho, microfraturas e o seu comportamento em longo prazo devem ser considerados na avaliação e escolha do material veneer.

AKÇA et al. ${ }^{2}$, também em 2002, realizaram um estudo para avaliar a compatibilidade entre a análise do elemento finito tridimensional e a análise com strain gauges na medição dos níveis de estresse em implantes dentais. 
Os autores utilizaram dois implantes posicionados num modelo experimental de polimetilmetacrilato, onde strain gauges foram colados na região cervical dos implantes, sobre os quais, sete próteses parciais fixas retidas por cimento foram fabricadas. Um modelo $3 \mathrm{D}$ dos strain gauges foi construído e ainda um terceiro modelo, o qual simulava osso humano. Uma carga vertical estática de $50 \mathrm{~N}$ foi aplicada em vários pontos, simulando carga posicionada axial e lateralmente, para análise através dos strain gauges e do elemento finito $3 \mathrm{D}$.

Os autores observaram que estatisticamente houve um aumento nos níveis de resistência entre os tipos de cargas aplicadas, sendo maior na carga lateral, na análise dos strain gauges. Além disso, comparando os dois modelos na referida carga a análise dos strain gauges apresentou níveis de resistência superiores aos registrados na análise do elemento finito 3D.

A conclusão deste estudo foi de que existem diferenças entre a análise do estresse gerado sobre próteses fixas implanto-suportadas, quando analisadas pelo elemento finito 3D e utilizando strain gauges. No entanto, existe compatibilidade entre os dois métodos na determinação da qualidade de resistência induzida sob carga aplicada.

Neste mesmo ano de 2002, TAKAHASHI et al. ${ }^{37}$, avaliaram a probabilidade de falha de três sistemas de resinas reforçadas por partículas minerais, em relação a coroas metalo-cerâmicas convencionais. Foram avaliados os sistemas Artglass, Targis e Estenia. Para este estudo 20 corpos de prova de cada material foram confeccionados, utilizando um cilindro de liga de ouro tipo IV, que após a fundição recebia o material veneer. As cerâmicas utilizadas foram a VMK95 e Degudent Universal. 
Os corpos de prova apresentavam um formato cilíndrico com $8 \mathrm{~mm}$ de altura e $8 \mathrm{~mm}$ de diâmetro. Estes corpos eram fixados numa base metálica por um parafuso de ouro e recebiam cargas compressivas em pontos distantes $1 \mathrm{e}$ $2 \mathrm{~mm}$ da periferia da mesa oclusal, simulando cargas excêntricas.

Os autores observaram que nas mesmas localizações da carga não houveram diferenças significativas na probabilidade de falha entre o grupo de corpos de metalo-cerâmica e os três sistemas de resina avaliados. Porém, recomendam minimizar o carregamento excêntrico de restaurações implantosuportadas com material veneer de resina, visando otimizar o índice de sucesso destes casos.

BASSIT et al. ${ }^{4}$, em 2002, realizaram um estudo "in vivo" e "in vitro" para avaliar a magnitude das forças geradas sobre próteses fixas implantosuportadas, quando se utilizavam diferentes materiais de recobrimento oclusal. Os autores utilizaram strain gauges colados nos pilares para medir a força transferida aos implantes, após a aplicação de uma força dinâmica. Foram avaliadas forças axiais aplicadas sobre coroas fabricadas em resina de polimetilmetacrilato e cerâmica.

As coroas eram ajustadas em relação cêntrica e supra oclusão, sendo que estas recebiam o primeiro contato na oclusão e mastigação. O mesmo protocolo de pesquisa foi aplicado num modelo "in vitro", no qual o implante foi fixado numa placa de aço e a força gerada por um peso de $164 \mathrm{~g}$, caindo de uma altura padronizada.

Os autores observaram que o tipo de material de recobrimento oclusal não influenciou a magnitude das forças geradas sobre as próteses fixas implanto-suportadas. Também que no teste "in vitro" houve uma pequena diferença pelo fato da força ser gerada por um impacto somente e o implante estar rigidamente ancorado. 


\section{PROPOSIÇÃO}

Interado do contexto biomecânico que envolve o complexo ossoimplante-prótese, o presente trabalho visa:

A. Avaliar "in vitro" a deformação sofrida por infra-estrutura de prótese fixa implanto-suportada, com extremidade livre (cantilever), fundida em liga de paládio-prata, e quando esta é revestida por resina acrílica e porcelana como materiais de recobrimento oclusal. 


\section{MATERIAL E MÉTODOS}

\subsection{Seleção da amostra}

Os componentes necessários para a realização da pesquisa foram obtidos junto à empresa Conexão Sistemas de Prótese Ltda (São Paulo, Brasil) que atendeu à solicitação enviando os seguintes componentes:

05 réplicas de fixação de $3,75 \mathrm{~mm} \times 10 \mathrm{~mm}$ - código - 13 - CNB

05 intermediários convencionais em 2 peças de $4 \mathrm{~mm}$ - código 09 $\mathrm{CNB}-\mathrm{B}$

05 cilindros de plástico para a fundição - código 96 - CNB

10 parafusos de titânio com fenda - código 108 - CNB

05 cilindros de ouro convencionais - código 12 - CNB

\subsection{Confecção do modelo mestre}

Um modelo mestre, desenvolvido por JAQUES ${ }^{20}$, apresentando forma circular, com $67 \mathrm{~mm}$ de diâmetro interno, $79 \mathrm{~mm}$ de diâmetro externo e $25 \mathrm{~mm}$ de altura, foi confeccionado em aço comum (Aço 1010/20), conforme as especificações do desenho (Figura 4.1). Cinco perfurações, com 3,75mm de diâmetro foram realizadas na porção superior do modelo mestre, de modo que as réplicas de fixação pudessem ser adaptadas com precisão.

Para evitar qualquer tipo de deslocamento, cada réplica foi fixada por meio de um parafuso tipo "Allen", sem cabeça (modelo M3 x 10mm), transfixando o modelo mestre no sentido horizontal. 


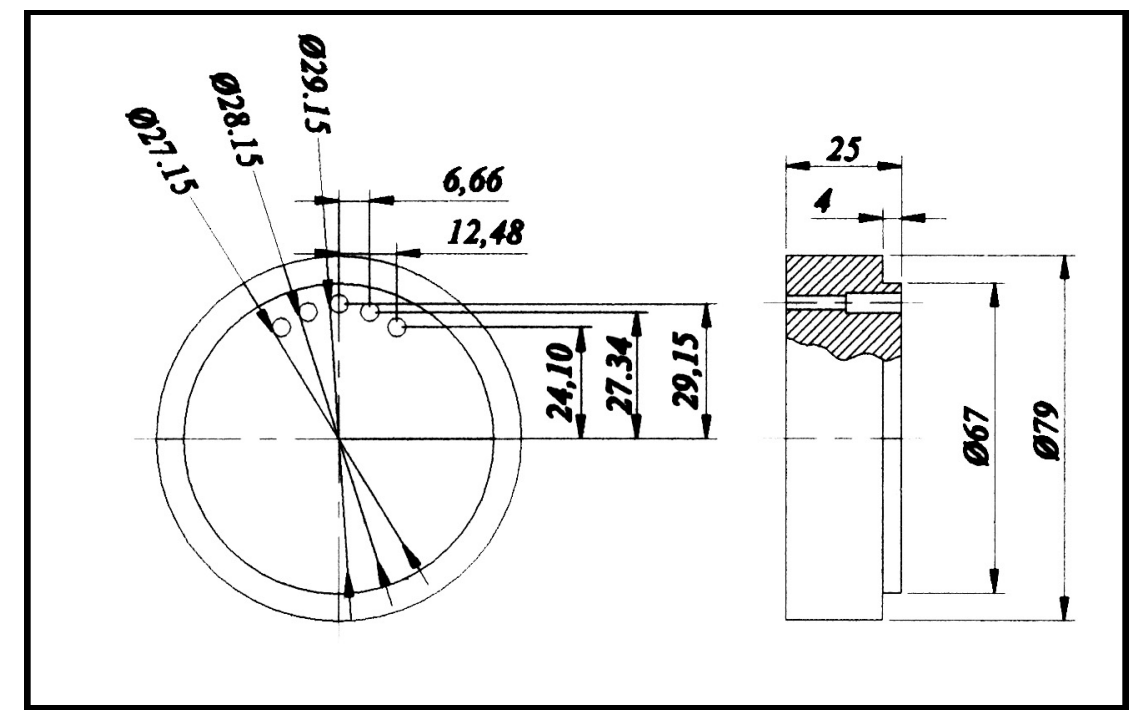

Figura 4.1 - Desenho esquemático do modelo-mestre.

Vista superior e em corte transversal

Partindo da perfuração mediana, as demais foram realizadas a uma distância de centro a centro, de $7 \mathrm{~mm}$, sendo o ângulo formado entre os centros da perfuração mediana e da mais distal, de 55ํ. Cada réplica de fixação foi, então, adaptada na sua respectiva perfuração, de maneira que sua porção superior ficasse ao nível da superfície do modelo mestre. A seguir, os intermediários convencionais de $4 \mathrm{~mm}$ de altura foram posicionados e parafusados com um torque de $20 \mathrm{Ncm}$, através de um dispositivo eletrônico de controle de torque (Nobel Biocare Torque Controller TM, Gotemburgo, Suécia) (Figuras 4.2 e 4.3). 


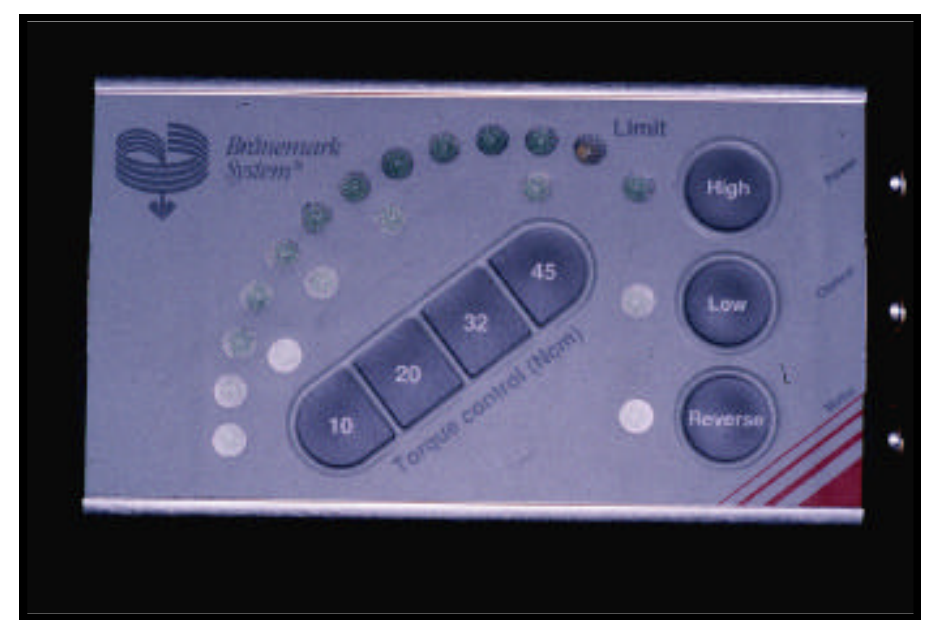

Figura 4.2 - Dispositivo eletrônico de controle de torque

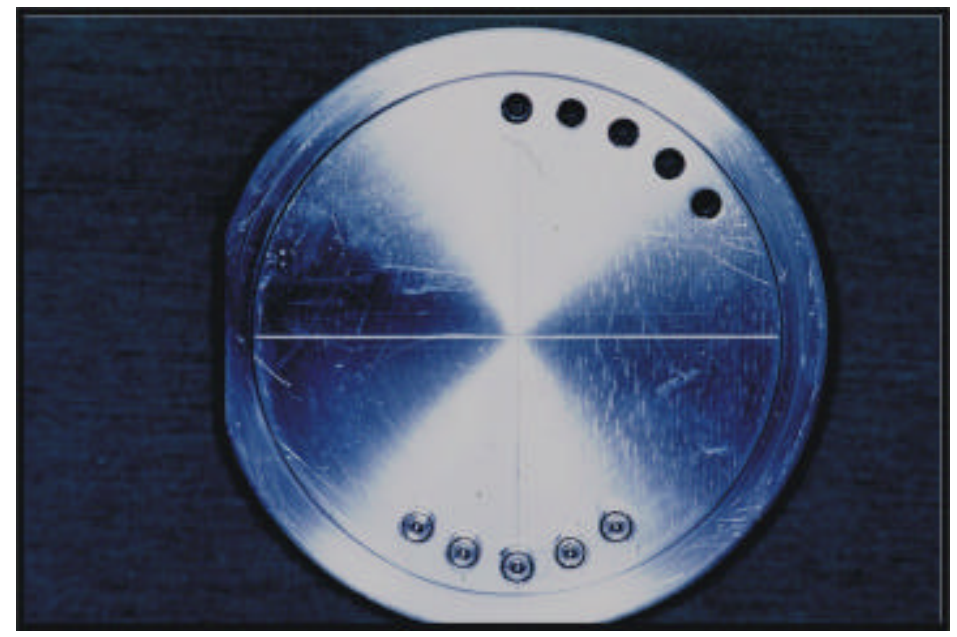

Figura 4.3 - Vista superior do modelo-mestre com os intermediários em posição 


\subsection{Confecção do corpo de prova}

\subsubsection{Infra-estrutura em liga de paládio-prata}

(Pors-on ${ }^{\circledR} 4$ - Degussa S.A., São Paulo, Brasil)

\subsubsection{Enceramento}

Para realizar o enceramento da infra-estrutura, inicialmente, os cilindros de ouro para fundição posicionou-se nos intermediários e parafusados, utilizando-se parafusos de titânio com fenda. Empregou-se cilindros de ouro uma vez que, a liga de paládio-prata pode ser fundida diretamente sobre os cilindros de ouro. Com o uso de cera para incrustação (Hard Inlay Wax Corning's Waxes - Corning Rubber CO, Inc.), esculpiu-se uma barra com as seguintes características: $75 \mathrm{~mm}$ de comprimento, $6 \mathrm{~mm}$ de largura e $4 \mathrm{~mm}$ de altura, sendo que a extensão da extremidade livre correspondia a $23,5 \mathrm{~mm}$, em ambos os lados (Figuras 4.4 e 4.5). Na porção superior das extremidades livres foram preparadas pequenas depressões, a uma distância de 10, 15 e 20mm do centro da réplica de fixação terminal, para permitir a acomodação da ponta aplicadora da carga. 


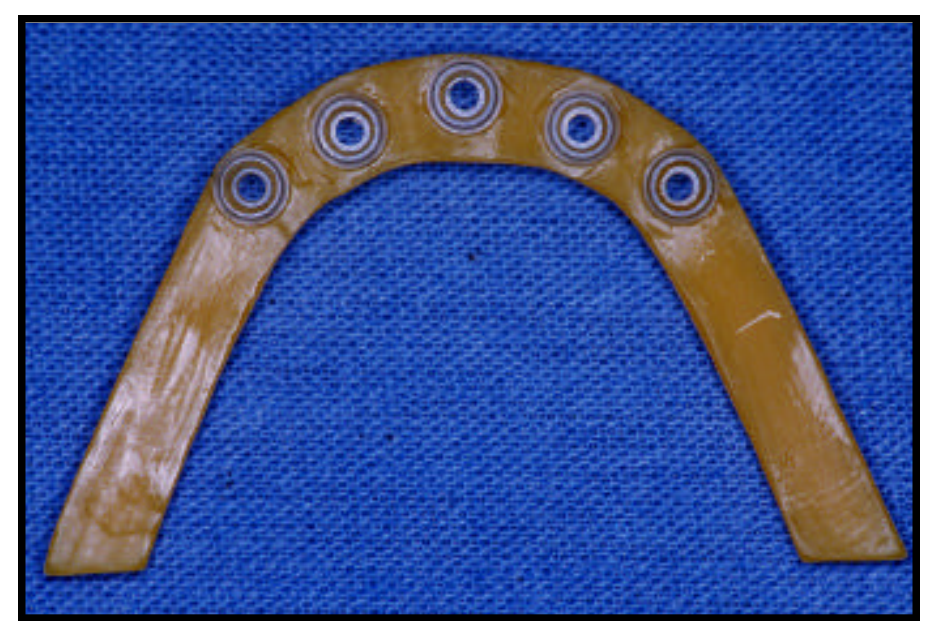

Figura 4.4 - Vista inferior do enceramento do corpo de prova

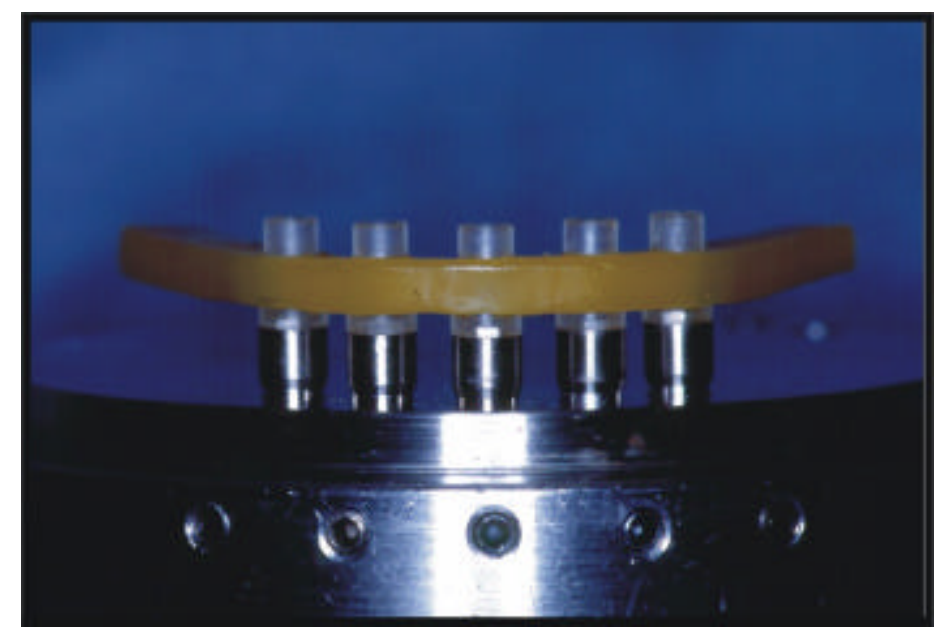

Figura 4.5 - Vista frontal do enceramento do corpo de prova no modelo-mestre

\subsubsection{Inclusão}

O padrão em cera, com os cilindros de ouro a ele incorporados, foi removido do modelo mestre e fixado na base formadora de cadinho. Aplicou-se um agente redutor de tensão superficial (Anti-bolhas Kota - Kota - Indústria e 
Comércio - São Paulo - SP), em toda a superfície do padrão em cera. A seguir, um anel de silicone com capacidade de $150 \mathrm{~g}$, foi adaptado à base formadora de cadinho e utilizou-se um revestimento do tipo aglutinado por fosfato de micropartículas (Talladium Micro-Fine 1700 - Talladium do Brasil Inc. - Comércio de Materiais de Prótese Odontológica), de acordo com as especificações do fabricante (16ml de líquido específico $+6 \mathrm{ml}$ de água para 1 envelope de $90 \mathrm{~g}$ ).

Para a espatulação do revestimento foi utilizada a técnica preconizada pelo fabricante do mesmo, que consistiu em incorporar o pó ao líquido, espatular por aproximadamente 10 segundos e levar a espatulação mecânica (Vacuum Power Mixer Plus - Whip Mix Corporation - USA), por 40 segundos.

Para a inclusão foi utilizada a técnica manual, com o auxílio de vibração mecânica. Num primeiro momento, os cilindros de plástico foram pincelados com o revestimento na sua porção interna e, posteriormente, foi realizado o preenchimento completo do anel de silicone. Aguardou-se o tempo de presa do revestimento, de acordo com as especificações do fabricante (25 minutos, a uma temperatura de $22{ }^{\circ} \mathrm{C}$ ), antes de prosseguir aos passos seguintes. 


\subsubsection{Fundição}

Após a remoção da base formadora de cadinho e do anel de silicone, o conjunto obtido na inclusão foi colocado no interior do forno (Radiance - Jelrus - USA), à temperatura exigida pela liga de paládio-prata de $760{ }^{\circ} \mathrm{C}$, para a eliminação da cera. A obtenção do aspecto da liga em seu ponto de liquefação determinou o momento de liberar a trava da centrífuga, para que o metal fosse injetado no interior do molde.

O cadinho cerâmico, previamente aquecido, foi posicionado no braço da centrífuga para fundição que foi ativada, sempre com a mesma quantidade de voltas. A liga Pors-on ${ }^{\circledR} 4$ - Degussa S.A., São Paulo, Brasil foi colocada no local apropriado e fundida de forma uniforme e gradual, através de um maçarico (RPM 247.5 - Swiss Made) com proporções adequadas de propano/oxigênio.

\subsubsection{Acabamento}

As desinclusões foram realizadas após o resfriamento e, então, aplicado um jato abrasivo de óxido de alumínio e esferas de vidro, com partículas de $100 \mu \mathrm{m}$ e pressão de $60 \mathrm{Lb} / \mathrm{pol}^{2}$, para remover os restos de revestimento. Os condutos de alimentação foram seccionados e a superfície inspecionada com uma lupa de 4 aumentos. A infra-estrutura concluída (Figura 4.10) pesou 17,379g, mensurados em uma balança de precisão (Balança GeHaka BG200). 


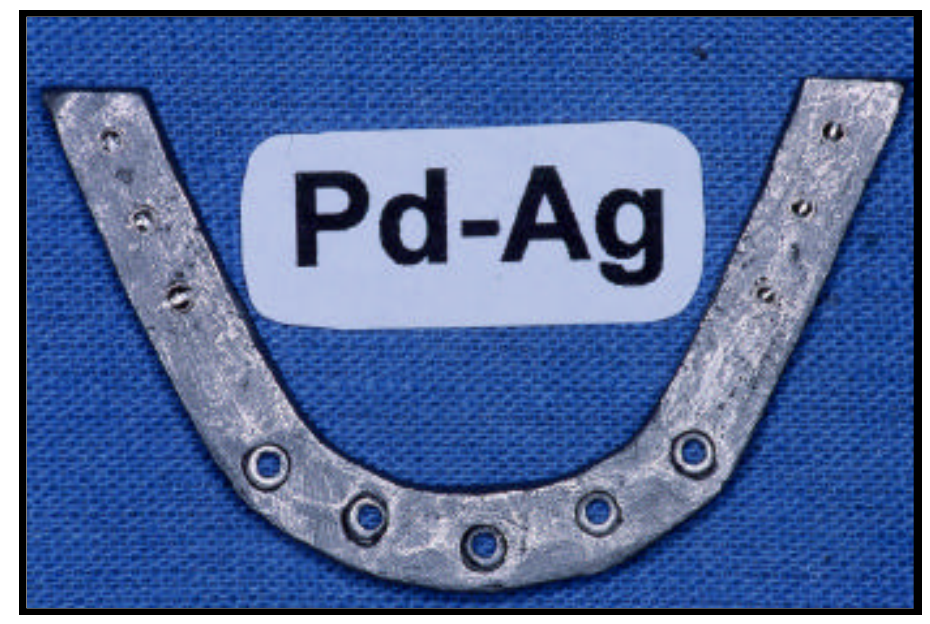

Figura 4.6 - Vista superior do corpo de prova em paládioprata, após o acabamento

Com o intuito de detectar defeitos grosseiros decorrentes do procedimento de fundição, a infra-estrutura foi radiografada no aparelho de $\mathrm{Rx}$ GE 100Kv (General Electric) com voltagem de 10MA, tempo de exposição de 18/60segundos e distância foco/filme de $40 \mathrm{~cm}$, utilizando-se uma película oclusal (Kodak - Ektaspeed plus - EO - 41P - Size 4 ). Não foram identificados defeitos através da radiografia.

Depois de finalizado o acabamento, a infra-estrutura retornou ao modelo mestre para a execução da mensuração do estresse gerado, através do uso de extensômetros lineares elétricos. 
Tabela 4.1 - Especificações da liga utilizada na fundição, segundo o fabricante.

\begin{tabular}{|c|c|c|c|c|c|}
\hline LIGA & LOTE № & CONTEÚDO & $\begin{array}{l}\text { INTERVALO } \\
\text { DE FUSÃO } \\
\left({ }^{\circ} \mathrm{C}\right)\end{array}$ & $\begin{array}{l}\text { MÓDULO DE } \\
\text { ELASTICIDADE } \\
\text { (GPa) }\end{array}$ & $\begin{array}{l}\text { PESO } \\
\text { ESPECÍFICO } \\
\left(\mathrm{g} / \mathrm{cm}^{3}\right)\end{array}$ \\
\hline $\begin{array}{l}\text { Pors-on } 4^{\circledR} \\
\text { (DegussaS.) }\end{array}$ & 120130 & $\begin{array}{l}\mathrm{Pd}-57,8 \% \\
\mathrm{Ag}-30 \%\end{array}$ & $\begin{array}{l}1175 \\
1275\end{array}$ & $95^{11}$ & 11,40 \\
\hline
\end{tabular}

\subsection{Aplicação do material de recobrimento sobre a infra-estrutura metálica}

A infra-estrutura metálica recebeu em cada uma de suas metades, tomando-se a linha média como referência, uma camada de porcelana e resina acrílica termopolimerizável, respectivamente, como descrito a seguir:

\subsubsection{Aplicação da porcelana}

Uma camada de $2,5 \mathrm{~mm}$ de espessura de cerâmica feldspática (Noritake EX-3, Noritake Co., Nagoya, Japan), foi aplicada em uma da metades da infra-estrutura metálica simulando uma situação clínica, seguindo as especificações do fabricante (figura 4.7). 


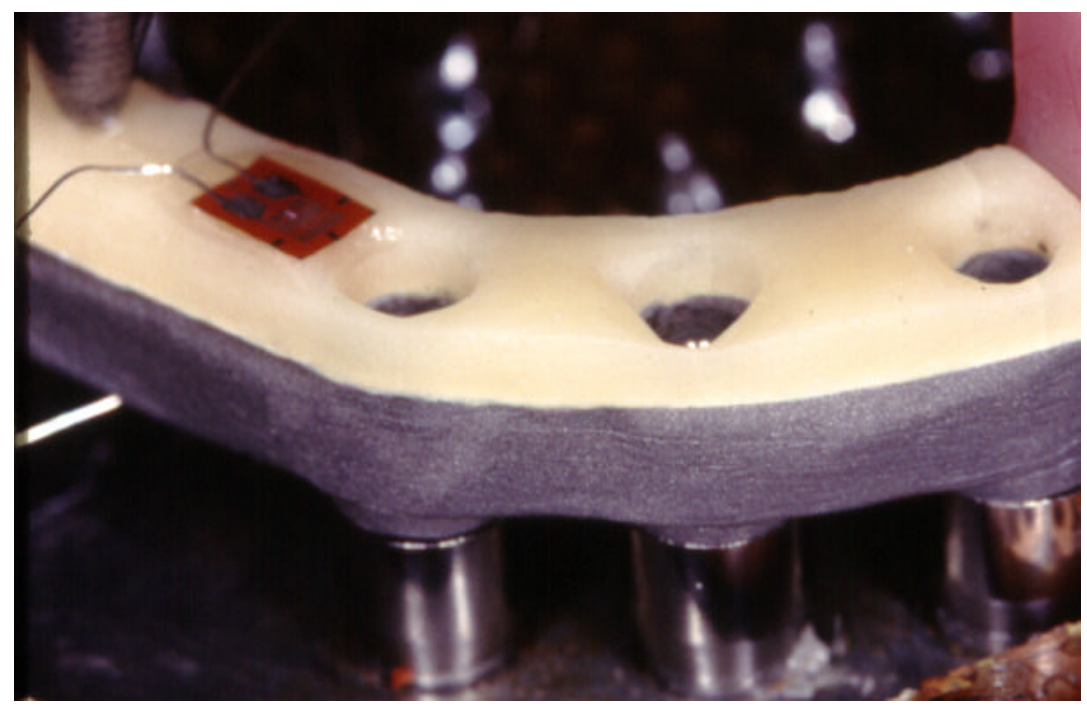

Figura 4.7- Porcelana aplicada em uma das metades da barra de PdAg

\subsubsection{Aplicação da resina acrílica termopolimerizável}

Uma camada de $10 \mathrm{~mm}$ de espessura de resina acrílica termopolimerizável (Palapress Vario®, Heraeus Kulzer GmbH \& Co. KG Kulzer, Wehrheim, Germany) foi aplicada sobre a outra metade da infra-estrutura metálica visando simular uma situação clínica (figura 4.8). Inicialmente foi levantado um enceramento com cera (Hard Inlay Wax - Corning's Waxes Corning Rubber $\mathrm{CO}$, Inc.), visando estabelecer a forma retangular que a resina tomaria sobre a infra-estrutura, ocupando apenas a face superior.

Com o objetivo de criar retenções mecânicas para a resina se prender a infra-estrutura metálica foi jateada com óxido de alumínio com granulometria de $50 \mu \mathrm{m}$ e a seguir jateada também com esferas de vidro de granulometria fina. Após o jateamento, a infra-estrutura ainda recebeu a aplicação de um agente silanizador para metais (Agente silano Kit Enforce/ Dentsplay), sendo posteriormente entulhada, prensada e polimerizada a resina seguindo o ciclo de polimerização preconizado por Turano ${ }^{40}$. 
Após a demuflagem a resina soltou-se da barra por não haver retenções mecânicas suficientes, uma vez que a barra apresentava a sua face superior lisa. Diante do ocorrido e visando não alterar as condições estruturais e de resistência da infra-estrutura, optou-se pela aplicação de adesivo à base de cianocrilato com a finalidade de fixar a resina sobre a infra-estrutura para a realização dos testes.

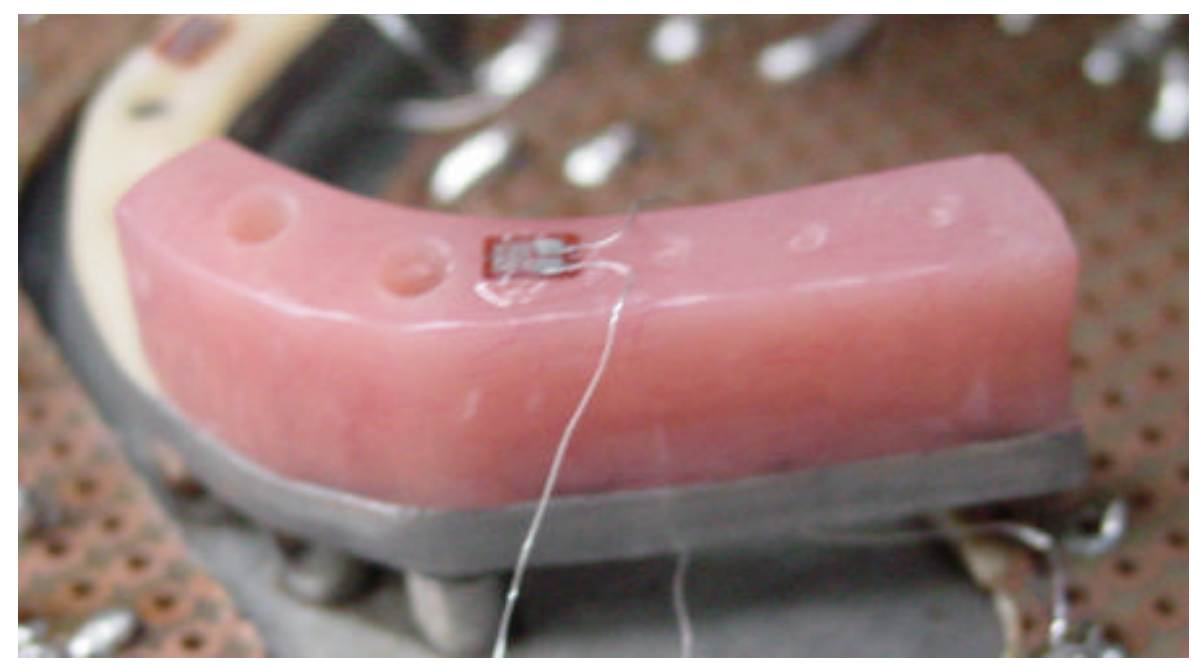

Figura 4.8 - Resina acrílica termopolimerizável aplicada sobre uma das metades da barra de PdAg 
Tabela 4.2 - Especificações dos materiais de recobrimento segundo os fabricantes.

\begin{tabular}{|c|c|c|}
\hline MATERIAL & $\begin{array}{l}\text { RESISTÊNCIA } \\
\text { TENSÃO } \mathbf{N} / \mathrm{mm}^{2}\end{array}$ & $\begin{array}{l}\text { RESISTÊNCIA À } \\
\text { CURVAMENTO N/mm }\end{array}$ \\
\hline $\begin{array}{l}\text { Porcelana feldspática } \\
\text { Porcelana Noritake EX-3 }\end{array}$ & 59,35 & 110,36 \\
\hline MATERIAL & $\begin{array}{l}\text { FLEXIBILIDADE } \\
\mathrm{N} / \mathrm{mm}^{2}\end{array}$ & $\begin{array}{l}\text { MÓDULO DE FLEXÃO } \\
\mathrm{N} / \mathrm{mm}^{2}\end{array}$ \\
\hline $\begin{array}{l}\text { Resina } \\
\text { termopolimerizável }\end{array}$ & & \\
\hline $\begin{array}{l}\text { Palapress } \\
\text { Heraeus Kulzer }\end{array}$ & 110 & 2140 \\
\hline
\end{tabular}

\subsection{Colagem dos extensômetros lineares elétricos}

A superfície da infra-estrutura foi limpa com acetona, previamente à colagem, após a aplicação do material de recobrimento, para remover qualquer resíduo que pudesse interferir no processo de fixação dos extensômetros lineares elétricos. Dois extensômetros lineares elétricos (KFG -02-120-C1-11, Strain Gauges - Kyowa Electronic Instruments Co., Ltd., Tóquio, Japão) (Figura 4.11) foram fixados com uma cola à base de cianoacrilato (Strain Gage Cement CC - 33 A -Kyowa Electronic Instruments Co., Ltd., Tóquio, Japão), nas superfícies inferior e superior da infra-estrutura próximo ao pilar distal de ambos os lados. Segundo as recomendações do fabricante era necessário aguardar uma hora, após a colagem, para que os testes pudessem ser executados. 


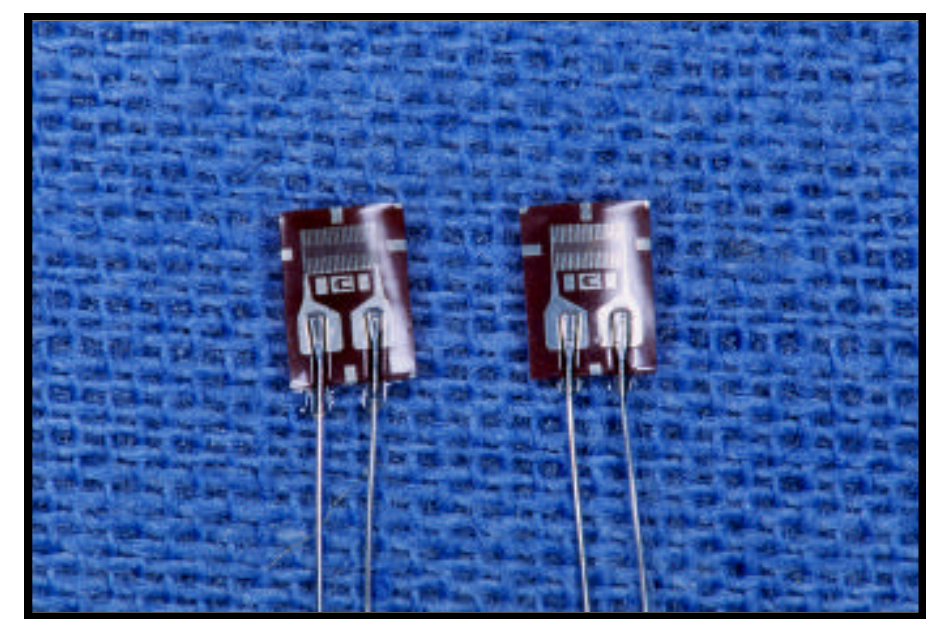

Figura 4.9 - Vista superior dos extensômetros lineares elétricos

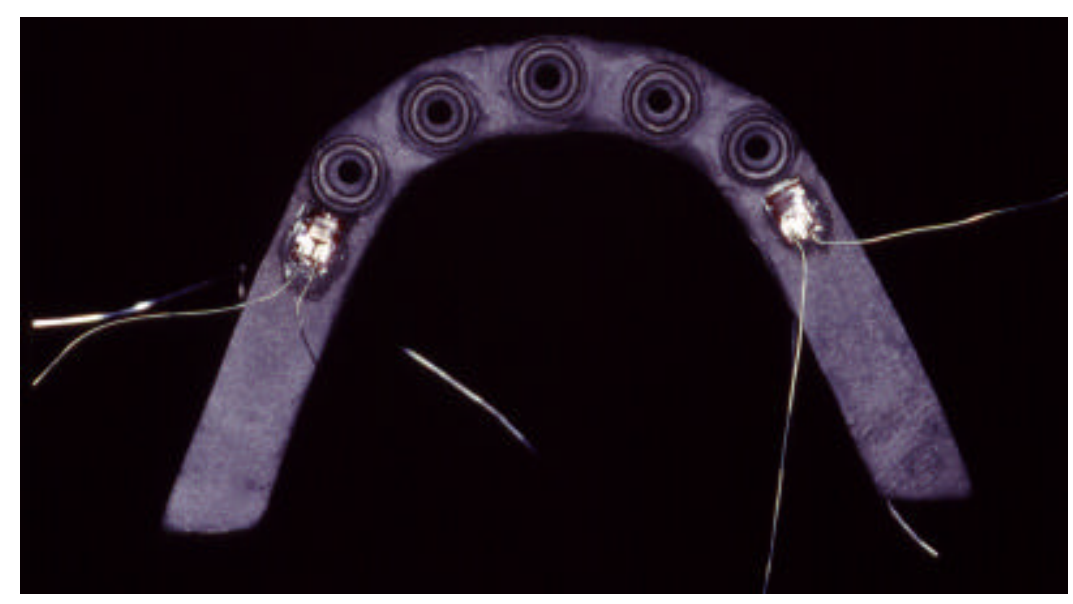

Figura 4.10 Colagem do extensômetro com adesivo à base de cianocrilato, sobre a superfície inferior da barra metálica

\subsection{Fixação do corpo de prova}

A infra-estrutura foi posicionada sobre os intermediários do modelo mestre e testada, manualmente, para verificar um possível efeito de báscula, o que não foi detectado. 
Para facilitar os procedimentos de leitura, as réplicas dos implantes foram numeradas de 1 a 5 , no sentido horário. Utilizou-se a seqüência de aperto dos parafusos de titânio proposta por JEMT ${ }^{20}$, na seguinte ordem: 2, 4, $3,1,5$.

Num primeiro momento, os parafusos de titânio foram apertados manualmente, através de uma chave de hexágono, até oferecerem resistência e fosse observada uma adaptação precisa, clinicamente, da infra-estrutura. A seguir, foi empregado um torque de $10 \mathrm{Ncm}$, através de um dispositivo eletrônico de controle de torque (Nobel Biocare Torque Controller TM, Gotemburgo, Suécia).

\subsection{Realização do teste}

Os extensômetros lineares elétricos foram conectados a uma placa de aquisição de dados (SC - 2042 - SG, National Instruments Corp., Austin, Texas, USA) que enviava sinais a uma placa de leitura (PCI - MIO - 16 XE 10, National Instruments Corp., Austin, Texas, USA), instalada em um microcomputador Pentium II $133 \mathrm{MHz}, 16 \mathrm{Mb}$. Os dados obtidos eram visualizados no monitor do computador, utilizando-se o programa LabVIEW FDS(CD_ROM), versão 5.1 para Windows (National Instruments Corp., Austin, Texas, USA).

Previamente à aplicação da carga, foi realizada uma leitura do estresse desenvolvido no extensômetro linear elétrico, decorrente da fixação do corpo de prova ao modelo mestre (Figura 4.11). Os resultados obtidos foram considerados como ponto de estresse zero, que posteriormente seriam comparados com os valores resultantes da aplicação da carga. 


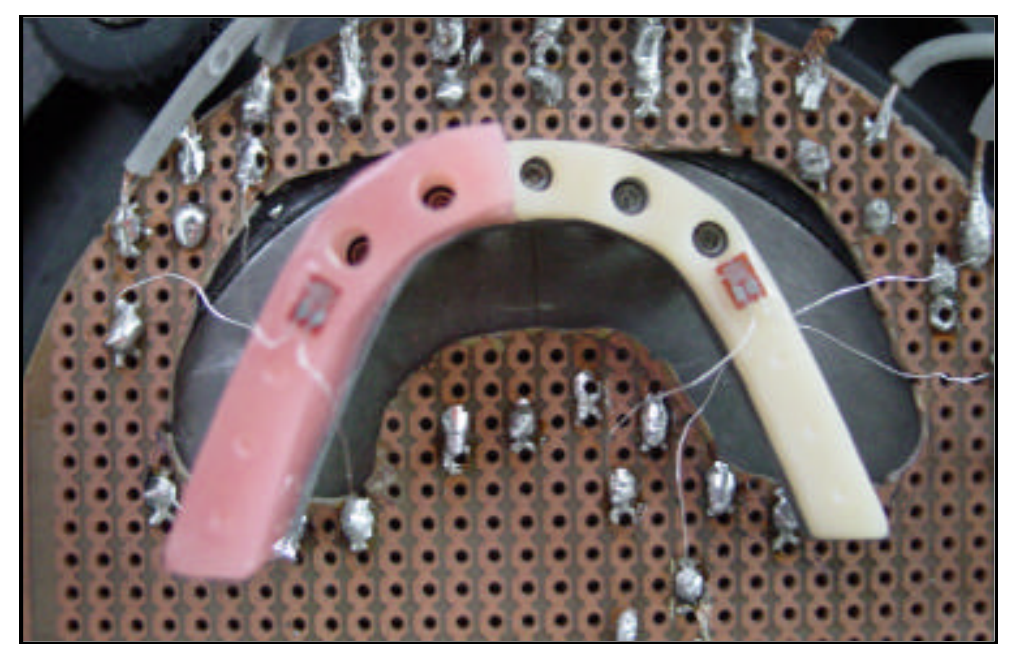

Figura 4.11 - Corpo de prova fixado ao modelo-mestre, os extensômetro lineares elétricos colados

Uma ponta em aço comum, na forma de lápis, foi fixada à célula de carga e uma força de $35,2 \mathrm{~N}$, estabelecida através de um teste piloto com os materiais envolvidos, foi aplicada, a uma velocidade de $0,5 \mathrm{~mm} / \mathrm{min}$, em cada ponto de referência pré-determinado na extremidade livre, a uma distância de 10, 15 e 20mm do centro da réplica de fixação terminal, em ambos os lados da barra, recobertos por porcelana e resina acrílica termopolimerizável (Figuras 4.12 e 4.13). Para cada ponto de aplicação da força foi realizada uma leitura da deformação. 


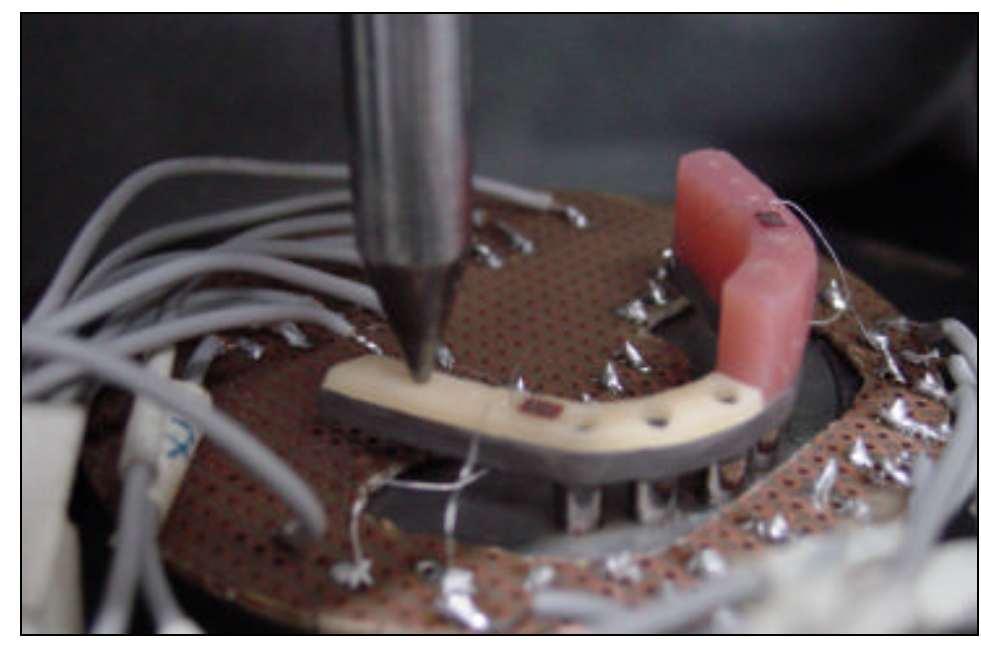

Figura 4.12 - Aplicação da carga na extremidade livre recoberta por porcelana feldspática

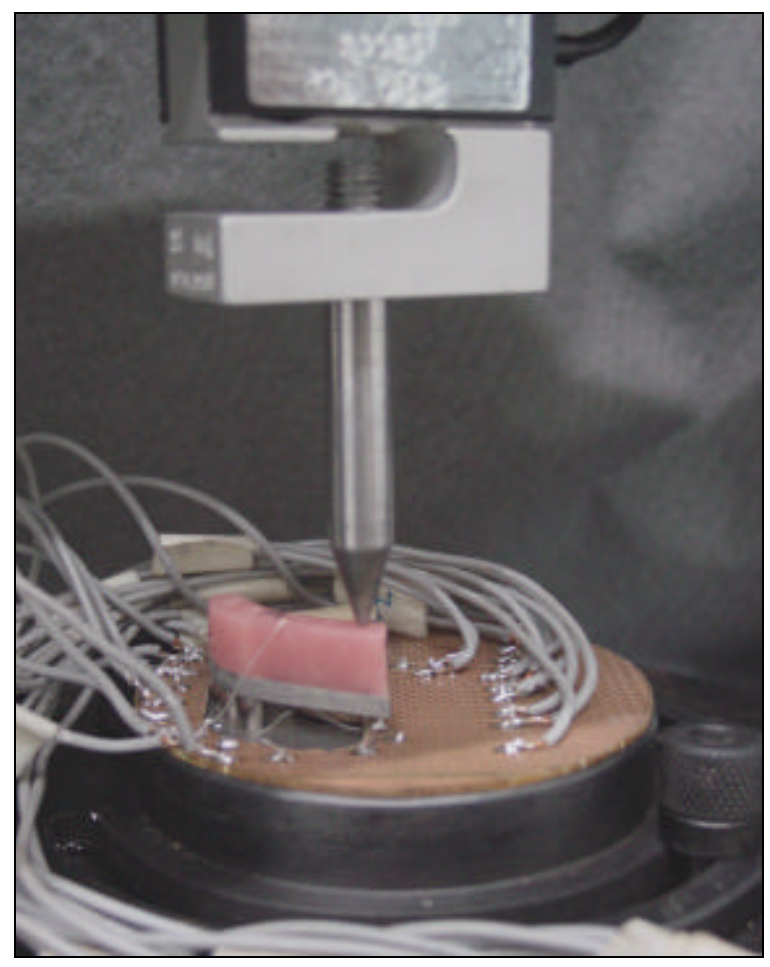

Figura 4.13 - Aplicação da carga na extremidade livre em resina acrílica termopolimerizável 


\section{8 ANÁLISE DOS DADOS}

Os valores de deformação obtidos nos testes foram representados em $\mu \varepsilon$ (micro strain), que não é uma unidade, mas sim uma forma adimensional de se simbolizar os valores de deformação.

O $\mu$ (micro) é uma letra grega que simboliza uma potência de dez, isto é, para este caso o micro vale $1 \times 10^{-6}$ ou 0,000001 .

Como os valores de deformação são sempre muito pequenos é comum recorrer a simbologia para simplificar a apresentação deste.

$O \varepsilon$ (strain) é uma letra grega que, em mecânica, significa tensão. Não é uma unidade de medida, serve para indicar que o numeral apresentado anterior a ele refere-se a um valor de deformação específica. Para entender-se como a deformação é um valor adimensional deve-se compreender a teoria de deformação.

Quando um determinado corpo de comprimento $L$ é solicitado por uma carga que consegue deformá-lo, este corpo sofre um aumento de seu comprimento. Esta variação de comprimento é simbolizada como $\Delta \mathrm{L}$, a esta variação é dado o nome de deformação absoluta, que é expressa em qualquer unidade de medida como o metro, o centímetro, o quilômetro, etc. A deformação específica nada mais é do que a relação entre a deformação absoluta e o comprimento inicial do corpo antes de ser solicitado, sua equação está expressa a seguir:

$$
\varepsilon=\frac{\Delta L}{L} \frac{(\mathrm{mm})}{(\mathrm{mm})},
$$


Percebe-se que tanto o comprimento $\mathrm{L}$ como a deformação absoluta $\Delta \mathrm{L}$ tem as mesmas unidades, isso faz com que a deformação específica fique sem unidade de medida. Se tivermos um valor de deformação específica de 0,000545, obtido pela divisão da eq. (4.1) ou por outra fonte de medição como experimental, a representação deste valor é dada como $545 \mu \varepsilon$ (quinhentos e quarenta e cinco micro strain ou quinhentos e quarenta e cinco microns de deformação).

Para que se obtivessem valores altamente confiáveis, bem como valores finais representativos e verdadeiros do todo, seguiu-se a seguinte seqüência na estruturação dos dados:

O experimento restringe-se a deformações de forma elástica, isto é, o corpo de prova a ser ensaiado, ao receber uma carga, sofre deformações de sua estrutura e quando esta carga é retirada o corpo volta às suas dimensões originais sem danificar-se ou apresentar vestígios do ensaio.

Repetições dos ensaios foram realizadas para que se pudesse compará-los e verificar se os valores se comportavam da mesma maneira, após serem submetidos a vários testes;

Como o corpo de prova foi composto por dois tipos de materiais, uma barra de PdAg, recoberta em uma de suas metades por porcelana e na outra por resina, foram colados dois strain-gauges, um próximo a réplica do implante terminal, na parte superior, que sofrerá durante o ensaio uma ação de flexão por tração, e outro, na barra de PdAg em sua parte inferior, que sofrerá uma flexão de compressão, alinhada ao extensômetro superior.

O ensaio seguiu o seqüênciamento crescente das distâncias, com marcações dispostas em 10, 15 e $20 \mathrm{~mm}$ partindo do centro da réplica do 
implante terminal. Para cada ponto de ensaio foram realizadas 10 seqüências, isto é, para cada ponto de ensaio obtinha-se 10 colunas de valores com velocidade de aquisição de 4 aquisições/segundo;

Os dados, conforme andamento do ensaio, seguiam para arquivos de extensão DAT, que eram salvos quando se finalizava o ensaio, na seqüência dos anteriores;

Depois de todos os dados armazenados e os ensaios concluídos, começou-se a separação, ordenação e análise dos dados. Essa análise seguiu parâmetros estatísticos com base na teoria dos Intervalos de Confiança;

Os dados foram transferidos para arquivos de extensão XLS do programa EXCEL, onde foram ordenados em colunas conforme ponto de ensaio e deformação positiva (superior - tração) ou negativa (inferior compressão);

Os dados apresentam três estágios percebidos durante o experimento; o primeiro, refere-se à situação onde não há variação de deformação e sim uma variação natural do aparelho de medida. Estes primeiros valores circundam o valor zero de deformação. O segundo estágio refere-se à fase onde a carga é aplicada e se tem a variação de deformação devido a resposta física do experimento e a leitura da strain-gauge.

No terceiro e último estágio a carga atinge o seu ponto máximo definido e, a deformação, por conseqüência, atinge seu valor máximo, referente à carga aplicada. Mesmo após atingir a carga de deformação máxima deixa-se o aparelho de aquisição continuar a leitura dos dados para que se obtenha um valor médio de deformação. A figura a seguir apresenta graficamente os três estágios dos dados. 


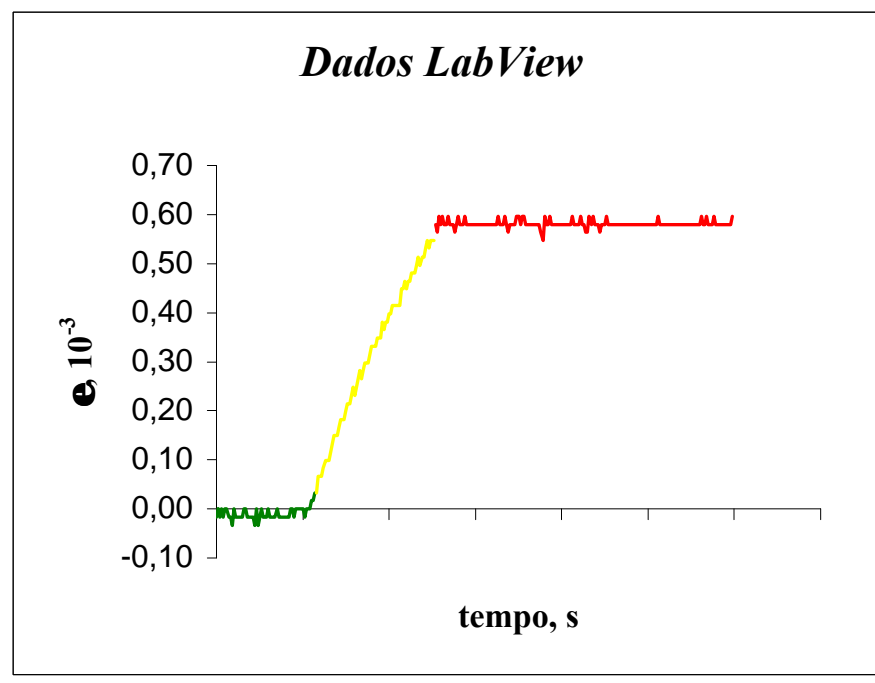

\begin{tabular}{|l|l|}
\hline----- & Dados Iniciais \\
\hline----- & $\begin{array}{l}\text { Dados Intermediários } \\
\text { de Variação da Carga }\end{array}$ \\
\hline----- & Dados Finais \\
\hline
\end{tabular}

Figura 4.14 - Estágios durante a coleta de dados pelo Lab View.

Esta análise tem por objetivo identificar o grau de deformação do material pesquisado, submetido à determinada carga, por isso, serão analisados apenas os dados finais de deformação. $O$ trabalho com esses dados identificará a média estatística dos valores de deformação.

A análise da figura 4.14 revela uma grande quantidade de pontos para este estágio do experimento, que serão relevados, dando-se preferência para análise da média e do desvio padrão, apenas os 100 últimos valores coletados, o que representa uma seleção mais confiável dos dados ocasionando uma diminuição do erro e uma maior conformidade dos mesmos.

Após a separação desses dados, utilizou-se o software ORIGIN para as análises estatísticas, entre elas o cálculo da média, desvio-padrão e variância. A tabela a seguir apresenta os valores estatísticos para o ensaio na parte inferior no ponto de $20 \mathrm{~mm}$ da barra de PdAg com Cerâmica. 
Tabela 4.3 - Dados coletados no ensaio para análise pelo software ORIGIN

\begin{tabular}{c|c|c|c|c|c}
\hline Colunas & Média & Desvio & Variância & Soma & $\begin{array}{c}\mathrm{N}^{\mathbf{o}} \text { de } \\
\text { Valores }\end{array}$ \\
\hline B & $-288,41121$ & 9,17514 & 0,91751 & $-28841,121$ & 100 \\
\hline C & $-298,06067$ & 9,18732 & 0,91873 & $-29806,067$ & 100 \\
\hline D & $-297,22882$ & 9,16447 & 0,91645 & $-29722,882$ & 100 \\
\hline E & $-316,86016$ & 8,82192 & 0,88219 & $-31686,016$ & 100 \\
\hline F & $-316,36109$ & 8,68624 & 0,86862 & $-31636,109$ & 100 \\
\hline G & $-298,89074$ & 9,13391 & 0,91339 & $-29889,074$ & 100 \\
\hline H & $-299,72437$ & 8,68678 & 0,86868 & $-29972,437$ & 100 \\
\hline I & $-301,05533$ & 8,55707 & 0,85571 & $-30105,533$ & 100 \\
\hline J & $-299,89074$ & 9,45281 & 0,94528 & $-29989,074$ & 100 \\
\hline K & $-299,22526$ & 8,51941 & 0,85194 & $-29922,526$ & 100 \\
\hline Media Total & $-301,57102$ & 8,66691 & 2,74072 & $-30157,102$ & 10 \\
\hline K & $-299,22526$ & 8,51941 & 0,85194 & $-29922,526$ & 100 \\
\hline I & $-301,05533$ & 8,55707 & 0,85571 & $-30105,533$ & 100 \\
\hline B & $-288,41121$ & 9,17514 & 0,91751 & $-28841,121$ & 100 \\
\hline G & $-298,89252$ & 9,13391 & 0,91339 & $-29889,252$ & 100 \\
\hline H & $-299,72437$ & 8,68678 & 0,86868 & $-29972,437$ & 100 \\
\hline Media Final & $-299,46174$ & 5,12598 & 2,29241 & $-1487,30869$ & 5 \\
\hline
\end{tabular}

Os valores na cor verde, contêm maior média, os valores na cor amarela contêm menor média. Os valores em azul, foram selecionados dos demais por terem os menores desvios padrões. E os valores em vermelho, são referentes ao valor final de deformação para este ensaio.

Com os dados estatísticos prontos, excluem-se os 2 valores com menor e maior média. Com os dados das 6 colunas de valores restantes selecionam-se as que apresentam os 5 menores valores de desvio padrão. Destes valores selecionados, faz-se a análise estatística chegando a valores finais de deformação. 
Para que o valor final a ser utilizado estivesse completo realizou-se a análise segundo a Teoria do Intervalo de Confiança. Esta teoria estatística indica qual o intervalo de valores confiáveis para uma população de amostras. Normalmente, para amostras experimentais é utilizada uma confiabilidade de $95 \%$, e este intervalo é calculado através da equação a seguir:

$$
\frac{1,96 \cdot \text { DesvioPadrão }}{\sqrt{n}}
$$

onde 1,96 é a constante referente a $95 \%$ de confiança e n o número de valores da amostra.

Para a tabela do ORIGIN, apresentada anteriormente, o valor de deformação é $299,4 \mu \varepsilon$. O mesmo procedimento foi utilizado para os demais pontos de aplicação de força e de ensaios. 


\section{Resultados}

Avaliando os índices de deformação do conjunto infra-estrutura e material de recobrimento, nos diversos pontos de aplicação da força de 35,2 N observou-se que:

a. Quando foi aplicada a força de $35,2 \mathrm{~N}$ no conjunto infra-estrutura/ porcelana:

a.1 Na marca de $10 \mathrm{~mm}$ do implante terminal a deformação na barra foi de $111,3 \mu \varepsilon$.

a.2 Na marca de $15 \mathrm{~mm}$ do implante terminal houve quase o dobro da deformação observada a $10 \mathrm{~mm}$. O índice de deformação na porcelana observado neste ponto foi de $201,3 \mu \varepsilon$, totalizando um aumento de $80,9 \%$.

a.3 Na marca de $20 \mathrm{~mm}$ o índice de deformação apresentou aumento, em relação a marca de $15 \mathrm{~mm}$, atingindo o valor de 299,4 $\mu \varepsilon$. Neste ponto, houve um aumento de $48,7 \%$ no índice de deformação em relação a marca de $15 \mathrm{~mm}$ e 169\% em relação à marca de $10 \mathrm{~mm}$.

Estes valores confirmam as colocações de TOM, WHITE et al., VAN ZYL et al., SERTGÖZ; GÜVENER, JAQUES, JANSON, de que o aumento da extremidade livre potencializa a deformação do conjunto infra-estrutura/material de recobrimento.

A tabela a seguir referenda os achados desta pesquisa, que também observou que o comprimento da extremidade livre influenciou nos índices de deformação da infra-estrutura metálica. 
Tabela 5.1 - Quadro comparativo dos índices de deformação em função do ponto de aplicação da carga, quando foi aplicada uma carga de 35,2 N

\begin{tabular}{l|l|c|c|c}
\cline { 3 - 5 } \multicolumn{2}{c}{} & \multicolumn{10}{c}{$\mathbf{m m}$} & $\mathbf{1 5} \mathbf{m m}$ & $\mathbf{2 0} \mathbf{m m}$ \\
\hline Porcelana & Compressão $(\mu \varepsilon)$ & 111,3 & 201,3 & 299,4 \\
\hline Resina & Compressão $(\mu \varepsilon)$ & 84,7 & 294,1 & 485 \\
\hline Pd-Ag & Compressão $(\mu \varepsilon)$ & 134,4 & 246,2 & 370,6 \\
\hline
\end{tabular}

b. A análise dos índices de deformação por compressão do conjunto infra-estrutura/resina acrílica termopolimerizável apresentou os seguintes resultados:

b.1 Na marca dos $10 \mathrm{~mm}$ do implante terminal a deformação medida na barra recoberta por resina apresentou o ponto mais rígido do ensaio, dentre os materiais de recobrimento atingindo $84,7 \mu \varepsilon$.

b.2 A deformação medida na resina na marca de $15 \mathrm{~mm}$ sofreu 0 aumento de $247,2 \%$, em relação à marca de $10 \mathrm{~mm}$, atingindo o valor de $294,1 \mu \varepsilon$.

b. $3 \mathrm{Na}$ marca de $20 \mathrm{~mm}$ em relação à de $15 \mathrm{~mm}$ do implante terminal observou-se um aumento no índice de deformação do conjunto infraestrutura/resina que apresentou o valor de $485 \mu \varepsilon$. Este aumento foi de $64.9 \%$.

c. Valores de deformação por compressão da infra-estrutura metálica sem recobrimento estético:

c.1 A deformação observada no ponto de $10 \mathrm{~mm}$, quando aplicada a força de $35,2 \mathrm{~N}$, foi de $134,4 \mu \varepsilon$. 
c.2 Na marca de $15 \mathrm{~mm}$ houve um aumento do índice de deformação em relação ao ponto de $10 \mathrm{~mm}$, da ordem de $83,18 \%$, alcançando o valor de $246,2 \mu \varepsilon$.

c.3 $\mathrm{Na}$ marca de $20 \mathrm{~mm}$ este valor sofreu uma variação de 50,5\%, aumentando para 370,6 $\mu \varepsilon$. Dados estes que confirmam a influência direta do comprimento da extremidade livre e o índice de deformação da infra-estrutura metálica.

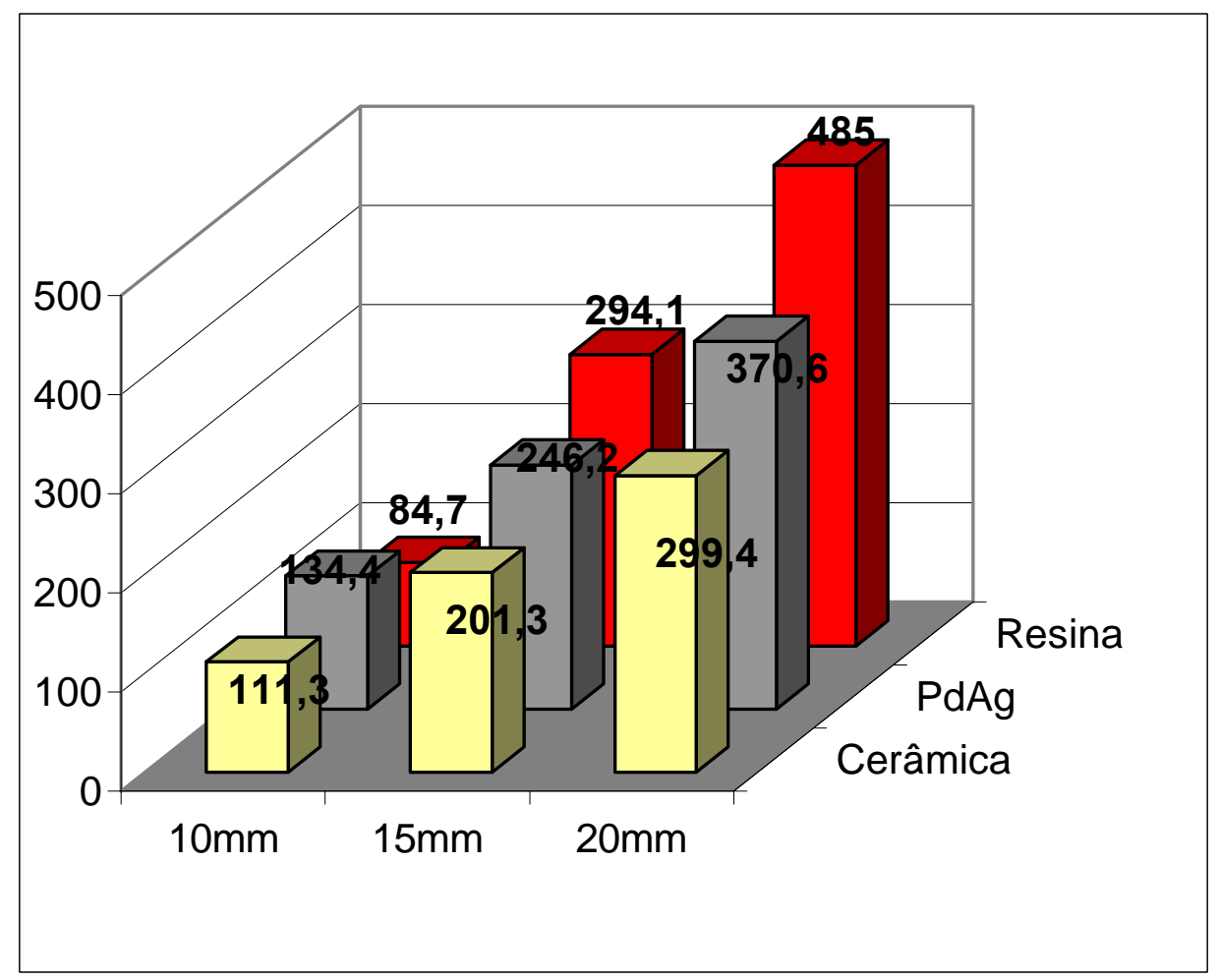

Figura 5.1 - Dados obtidos pelo teste de deformação por compressão. 


\section{Discussão}

A preocupação com a biomecânica das próteses fixas implantosuportadas reporta-nos aos experimentos de SKALAK ${ }^{33}$, que já demonstravam ser este assunto de vital interesse para a longevidade destes trabalhos.

A busca de materiais que suprissem deficiências técnicas e que otimizassem a função estética levou diversos pesquisadores como ZARB ${ }^{46,47}$,

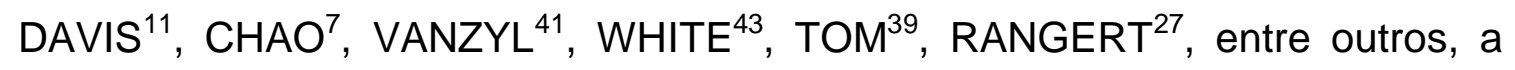
desenvolverem intensa investigação no intuito de identificar a influência dos princípios biomecânicos sobre os materiais utilizados e possíveis combinações até então não testadas.

A disposição correta dos implantes dentro do espaço edêntulo a ser reabilitado permitiria uma melhor distribuição das forças incidentes sobre 0 sistema prótese-implante-osso. Porém, limitações ósseas têm exigido o uso de próteses com extensões em cantilever. Estas próteses obtiveram maior sucesso no arco mandibular em função da quantidade e qualidade óssea, o que permite a colocação de extensões em cantilever de 15 a $20 \mathrm{~mm}$, segundo autores como RUBO et al. ${ }^{28}$, TOM ${ }^{39}$, WHITE et al. ${ }^{43}$, VAN ZYL et al. ${ }^{41}$, SERTGÖZ; GÜVENER ${ }^{31}$, entre outros.

Também, baseado nas limitações mecânicas, SCHACKLETON ${ }^{32}$ recomenda a extensão do cantilever em $15 \mathrm{~mm}$, em média, como forma de prevenir a indução de momentos de torsão sobre os elementos de ancoragem. Esta extensão em geral, possibilita a colocação de um ou dois dentes suspensos, completando o arco dental até segundo pré-molar ou primeiro molar. 
No arco maxilar este dimensionamento está mais limitado em função da baixa quantidade e qualidade óssea. Extensões exageradas de cantilever podem levar a uma sobrecarga do sistema. Por isto, recomenda-se uma extensão máxima de 10 a $12 \mathrm{~mm}$ para distal do último implante.

A mecânica de funcionamento da extensão em cantilever foi abordada por RANGERT et al. ${ }^{27}$ que a comparam a um sistema de alavancas de Classe I, onde os implantes representam o braço de resistência, o cantilever o braço de potência e o fulcro, ou eixo de rotação, se encontra no implante terminal.

A disposição dos implantes em curva é preferível ao arranjo linear, segundo RUBO et al. ${ }^{28}$ e RANGERT et al. ${ }^{27}$, por proporcionar um aumento do braço de resistência amenizando a geração de forças de tensão sobre os implantes. Por isto, a extensão em cantilever exagerada promove um desequilíbrio neste sistema de forças, induzindo a falhas mecânicas das próteses fixas implanto-suportadas de extremo livre.

A compreensão da distribuição de cargas e geração de tensões dentro de um sistema de prótese sobre implantes necessita de um estudo que permita avaliar qualitativamente e quantitativamente os níveis de estresse gerados durante a função. Para tal, SPIEKERMANN ${ }^{35}$ recomenda a utilização da análise do elemento finito tridimensional, que tem se mostrado eficiente e precisa, permitindo o cálculo da distribuição e concentração de estresse, bem como a deformação dos componentes do sistema através de uma leitura computadorizada.

A avaliação da deformação de materiais usados em próteses sobre implantes, utilizando-se extensômetros lineares elétricos (strain gauges), foi usada por diversos autores como DAVIS ${ }^{11}, \mathrm{ZARB}^{46,47}, \mathrm{CHAO}^{7}, \mathrm{SERTGÖZ}^{30}$, 
CIBIRKA $^{8}$, JACQUES ${ }^{20}$, HOLLWEG ${ }^{15}$ e JANSON $^{19}$ e, é recomendada por AKÇA et al. ${ }^{2}$, em 2002, como sendo confiável e precisa.

Os extensômetros lineares elétricos são pequenas resistências elétricas, que à mínima deformação sofrida, alteram a resistência criada à corrente elétrica de baixa intensidade que as percorre. $O$ sinal elétrico captado pelos extensômetros é enviado a uma placa de aquisição de dados para ser transformado em sinal digital, possibilitando a leitura, em um microcomputador, da deformação sofrida na extremidade livre da prótese fixa implanto-suportada. Estes pequenos terminais de extensometria têm a capacidade de registrar, com grande precisão, qualquer deformação que ocorra quando submetidos à ação de uma força de compressão e/ou tensão.

A associação de materiais que tornem a estrutura da prótese fixa implanto-suportada mais rígida e com maior capacidade de absorver as forças incidentes sobre sua estrutura vem sendo foco de estudos por parte de autores como ZARB ${ }^{46,47}$; DAVIS $^{11}$, que desenvolveram pesquisas baseadas na tecnologia da análise do elemento finito, avaliando o uso de ligas alternativas de metais não nobres para baixar o custo destas próteses e melhorar suas propriedades mecânicas.

Os desenvolvimentos de ligas de Paládio-prata, inicialmente, seguidos por ligas de Cobalto-Cromo deram novo alento aos pesquisadores.

JAQUES $^{20}$ em recente trabalho, demonstrou, pela utilização de extensômetros lineares elétricos, que as ligas de Cobalto-Cromo são grandes aliados na elaboração de infra-estruturas mais rígidas e conseqüentemente com menor deformação elástica. Este fator torna o referido material adequado para equilibrar a distribuição de forças sobre o sistema prótese-implante-osso. A utilização de ligas de Cobalto-Cromo permite extensões em cantilever maiores, 
porém com a mesma deformação elástica que infra-estruturas com extensões em cantilever menores confeccionadas em liga de Paládio-Prata.

O estudo da deformação das bases metálicas que unem os implantes, no entanto, não encerra o problema da distribuição de cargas. Isto, porque a infra-estrutura deve ser recoberta por um material que reproduza a forma e estética dos dentes naturais.

Esse material, em relação à rigidez da infra-estrutura, pode ser tanto mais flexível (resina acrílica), quanto mais rígido (cerâmica), tornando mais complexo o problema.

Por outro lado, o uso de materiais mais resilientes, como recobrimento estético das superfícies oclusais, não resulta em efeitos deletérios ao conjunto prótese-implante-osso, como observaram CIBIRKA ${ }^{8}$, HOBKIRK; PSSAROS ${ }^{17} \mathrm{e}$ ISMAIL $^{18}$.

No intuito de mesclar materiais biomecanicamente compatíveis com estruturas de suporte e baseados nos estudos de ASSIF et al. ${ }^{3}$, STEGARIOU et al. ${ }^{36}$, GRACIS et al. ${ }^{13}$, RUBO et al. ${ }^{28}$, SERTGÖZ; GÜVENER ${ }^{31}$, RANGERT et al. ${ }^{27}$, buscou-se neste trabalho desenvolver uma associação entre liga de PdAg e os materiais de recobrimento oclusal: porcelana e resina acrílica termopolimerizável, e assim observar o efeito que esses materiais teriam sobre a rigidez da barra quando submetida à carga.

Mesmo que apontado por ÇIFTÇI; CANAY ${ }^{9}$ como excelente material de recobrimento, os cerômeros não foram alvo desta pesquisa, pois são as resinas acrílicas as mais comumente empregadas nas reabilitações com próteses fixas implanto-suportadas de arco total, principalmente nos casos que, no Brasil, tornaram-se conhecidos como "protocolo". 
Após a aplicação dos materiais de recobrimento sobre as respectivas metades da infra-estrutura e submetidos à metodologia anteriormente citada, observaram-se algumas particularidades.

A carga aplicada no ponto mais próximo do implante terminal, tanto para a resina acrílica termopolimerizável, porcelana e a barra sem recobrimento estético, gerou valores de deformação menores que nos pontos mais distantes, justificando a influência do comprimento da extensão em cantilever nos índices de deformação, como preconizam WHITE ${ }^{43}$ e SCHACKLETON ${ }^{32}$. Quanto maior a extensão da extremidade livre suspensa da infra-estrutura, maior a deformação ocorrida, como foi observado por JANSON $^{19}$, mesmo que utilizando ligas metálicas que proporcionem maior rigidez a esta infra-estrutura.

Comparando os resultados obtidos na infra-estrutura sem recobrimento estético com a recoberta com a resina acrílica e a porcelana pode-se observar que:

O acréscimo de porcelana na espessura de $2,5 \mathrm{~mm}$, que é um consenso na literatura, proporciona um aumento na rigidez do conjunto infraestrutura/material de recobrimento e, conseqüentemente reduzindo os índices de deformação.

O acréscimo de resina acrílica revelou que houve diminuição da deformação no ponto de $10 \mathrm{~mm}$, porém, nos demais pontos ocorreram aumentos significativos nos índices de deformação. Este fato se deve provavelmente às características da resina acrílica que tem um módulo de elasticidade menor que a porcelana e, também pelo fato da camada de resina ser de maior espessura, $10 \mathrm{~mm}$. Fato este que gerou uma dissipação de forças na área, quando aplicada à carga no ponto de $10 \mathrm{~mm}$, proporcionando uma 
menor deformação da barra. Porém, posteriormente o efeito de alavanca do braço de cantilever elevou estes valores a patamares significativos, resultando em grande deformação nos pontos de 15 e $20 \mathrm{~mm}$.

Em comparação percentual entre os resultados de deformação com recobrimento, tendo como base o material sem recobrimento temos:

Tabela 6.1 -Análise comparativa dos percentuais de deformação entre os materiais estudados

\begin{tabular}{|c|c|c|c|}
\hline & $10 \mathrm{~mm}$ & $15 \mathrm{~mm}$ & $20 \mathrm{~mm}$ \\
\hline Resina - PdAg & $-37 \%$ & $+19,5 \%$ & $+31 \%$ \\
\hline Cerâmica - PdAg & $-17 \%$ & $-18 \%$ & $-19 \%$ \\
\hline
\end{tabular}

Os valores com sinal negativo representam uma redução percentual de deformação em relação à deformação ocorrida na barra de PdAg sem recobrimento, os valores com sinais positivos, representam um aumento de deformação com relação a mesma barra.

Observando os valores acima descritos, verificamos 0 melhor desempenho dos conjuntos barra de PdAg sem recobrimento e porcelana/PdAg em relação à infra-estrutura de $\mathrm{PdAg}$ recoberta por resina, exceção feita ao ponto de $10 \mathrm{~mm}$ de distância do implante terminal.

$\mathrm{Na}$ marca de $10 \mathrm{~mm}$ o conjunto infra-estrutura/porcelana apresentou um índice de deformação $17 \%$ menor que a infra-estrutura sem recobrimento e $31,4 \%$ maior que o conjunto resina/PdAg.

A porcelana proporcionou um enrijecimento do conjunto, suportando melhor, de modo geral, as forças de deformação aplicadas. 
Os valores de deformação por compressão encontrados na pesquisa demonstram que o conjunto infra-estrutura/resina apresenta índices de deformação expressivamente maiores que o conjunto infra-estrutura/porcelana, exceto no ponto de $10 \mathrm{~mm}$ onde a resina apresenta índice menor de deformação que a porcelana, fato este atribuído à característica física da resina que possui um módulo de elasticidade menor que as porcelanas e conseqüentemente permite uma maior deformação elástica deste material.

Observa-se que os valores de deformação por compressão na resina acrílica seguiram uma relação maiores distâncias, maiores deformações. A deformação aumenta de 10 para $15 \mathrm{~mm}$ e de 15 para $20 \mathrm{~mm}$. Este comportamento é resultado da flexão da resina em função do aumento do braço de alavanca na extremidade livre, isto é, um aumento no momento aplicado pela carga.

A equação abaixo exemplifica este fato.

$$
M=F \cdot d
$$

Do ponto de vista da escolha de um ou outro material de recobrimento, dados os resultados clínicos observados com ambos materiais, pode-se dizer que o discernimento de cada profissional diante de um caso específico deve ser respeitado, uma vez que cada material dentro de suas particularidades proporciona vantagens e desvantagens de acordo com cada caso específico.

O objetivo deste trabalho foi fornecer elementos para que essa escolha se dê baseada em mais informações sobre o comportamento dos materiais envolvidos. O que se demonstrou aqui é que a porcelana torna mais rígida a infra-estrutura, ao passo que a resina acrílica propicia maior deformação ao conjunto. 


\section{7- Conclusão}

As respostas, encontradas, aos questionamentos iniciais revelaram-se, com o desenvolvimento deste trabalho, um importante instrumento de apoio aos profissionais na busca e escolha de materiais que otimizem a estética e a função dos trabalhos de prótese fixa implanto-suportadas. Portanto, a partir da análise da deformação gerada em infraestrutura de próteses fixas implantosuportadas, por meio do uso de extensômetros - objeto deste estudo - chegouse a conclusão de que:

O material de recobrimento resina acrílica proporcionou maior rigidez quando o braço de cantilever foi curto e um aumento significativo de deformação quando este aumentou seu comprimento.

O material de recobrimento à base de porcelana propicia maior rigidez ao conjunto e conseqüentemente menor deformação, quando comparado com a associação entre infra-estrutura e resina e a infra-estrutura sem recobrimento.

A extensão do cantilever tem influência decisiva nos índices de deformação, mesmo quando associamos materiais de recobrimento estético a uma infra-estrutura metálica.

São necessários mais estudos com relação ao uso das resinas acrílicas no que diz respeito à espessura ideal da camada de recobrimento, visando minimizar a deformação ocorrida nas infra-estruturas de próteses fixas implanto-suportadas de arco total. 


\section{REFERÊNCIAS BIBLIOGRÁFICAS}

1. ADELL, R. et al. A 15-year study of osseointegrated implants in the treatment of the edentulous jaw. Int. J. oral Surg., v. 10, p. 387-416, 1981.

2. AKÇA, K. et al. A comparison of three-dimensional finite element stress análisis with "in vitro" strain gauge measurements on dental implants. Int. J. Prosthodont., v. 15, n.2, p. 115-21, 2002.

3. ASSIF, D.; MARSHAK, B.; HOROWITZ, A. Analysis of load transfer and stress distribution by an implant-supported fixed partial denture. $\mathbf{J}$. prosth. Dent., v. 75, n. 3, p. 285-91, Mar. 1996.

4. BASSIT, R. et al. In vivo registration of force development with ceramic and acrylic resin oclusal materials on implant-supported prostheses. The International Journal of oral \& Maxillofacial Implants, v. 17, n.1, p. 17-23, 2002.

5. BRANEMARK, P.I. Osseointegration and its experimental background. J. prosth. Dent., v. 50, n. 3, p. 399-409, 1983.

6. BRUNSKI, J. Biomaterials and biomechanics in dental implant desing. Quintessence Int., v. 3,n. 2, p. 87-97, 1988.

7. CHAO, Y. et al. A study into the use of chromium-cobalt alloy for constructing the framework for osseointegrated prostheses. Clinical mat., v. 3, p. 309-15, 1988.

8. CIBIRKA, R. M. et al. Determining the force absorption quotient for restorative materials used in implant oclusal surfaces. J. prosthetic Dent., v. 67, p. 361-64, 1992.

9. ÇIFTÇI, Y.; CANAY, S. The effect of veneering materials on stress distribuition in implant-supported fixed prosthodontics restorations. The International Journal of oral \& Maxillofacial Implants, v. 15, n. 4, p. 57182, 2000. 
10.DAVIS, D.M. ; ZARB, G.A. ; CHAO Y. Studies on frameworks for osseointegrated prostheses: Part 1. The effect of varying the number of supporting abutments. Int. J. oral Maxillofac. Implants, v. 3, n. 3, p. 197201, Fall 1988.

11. DAVIS, D.M. et al. Studies on frameworks for osseointegrated prostheses: part 2. the effect of adding acrylic resin or porcelain to from the occusal superstructure. Quintessence Int., v. 3, n.4, p. 275-80, 1988.

12. FALK,H. et al. Occlusal force pattern in dentitions with mandibular implantsupported fixed cantilever prostheses occluded with complete dentures. Int. J. oral Maxillofac. Implants, v. 4, n.1, p. 55-62, 1989.

13. GRACIS,S. et al. Shock-absorbing behavior of five restorative materials used on implants. Int. J. Prosthodontics, v. 4, n.3, p.282-91, 1999.

14. GOLL, G.E. Production of accurately fitting full-arch implant framework: Part I - Clinical procedures. J. prosth. Dent., v. 66, n. 3, p. 377-84, Set. 1991.

15. HOLLWEG, H. Análise da passividade de adaptação de infra-estruturas para prótese fixa implanto-suportada, através do uso de extensômetros, Bauru, 2000, 71 p. Tese ( Doutorado ) - Faculdade de Odontologia de Bauru, da Universidade de São Paulo.

16. HULTERSTRÖM, M.; NILSSON, U. Cobalt-chromium as a framework material in implant-supported fixed prostheses: A 3-year follow-up. Int. J. oral Maxillofac. Implants, v. 9, n. 4, p. 449-54, 1994.

17. HOBKIRK, J.A.; PSARROS, K.J. The influence of oclusal surface material on peak masticatory forces using osseointegrated implant-supported prostheses. Int. J. of oral Maxillofac. Implants, v. 7, n. 3, p. 345-52, 1992.

18. ISMAIL, Y.H. et al. Comparative study of various oclusal materials of implant prosthodontics. Diagnostic Systems/Implantology Research, n. 765, p. 962, 1989. /abstract/

19. JANSON, V. Análise da deformação gerada em infra-estruturas de prótese fixa implanto-suportada, através do uso de extensômetros . 
Bauru, 2001. 74 p. Dissertação ( Mestrado) - Faculdade de Odontologia de Bauru, Universidade de São Paulo.

20. JAQUES, L. Análise do estresse gerado em componentes de prótese fixa implanto-suportada, através do uso de extensômetros. Bauru, 2000.

71 p. Dissertação ( Mestrado ) - Faculdade de Odontologia de Bauru, Universidade de São Paulo.

21.JEMT, T. Failures and complications in 391 consecutively inserted fixed prostheses supported by Brånemark implants in edentulous jaw: a study of treatment from the time of prosthesis placement to the first annual checkup. Int. J. oral Maxillofac. Implants, v. 6, n. 3, p. 270-6, Fall 1991.

22. KIRSCH A., ACKERMANN, KL. The IMZ osteointegrated implant system.

Dent. Clin. North Amer., v. 33, p. 733-91, 1989.

23. LEUNG, N.; ZARB, G.A.; PILLIAR, P. Casting of prosthetic superstructures in tissue integrated dental prostheses. J. dent. Res., v. 62, p. 293, 1983. / Abstract n. 1112/

24. LUNDQVIST, S.; CARLSSON, C. Maxillary fixed prostheses on osseointegrated dental implants. J. prosth. Dent., v. 50, n. 2, p. 262-70, Aug. 1983.

25. MILLINGTON, N.D.; LEUNG, T. Inaccurate fit of implant superstructures. Part I: stresses generated on the superstructure relative to the size of fit discrepancy. Int. J. Prosth., v. 8, n.6, 1995.

26.PAPAVASILIOU, G. et al. Three-dimensional finite element analysis of stress-distribuition around single tooth implants as a function of bony support, prosthesis type, and loading during function. Int. prosthet. Dent., v. 76, n. 6, p. 633-48, dec. 1996.

27. RANGERT, B. et al. Forces and Moments on Branemark implants. Int. J. oral Maxillofac. Implants, v. 4, n. 3, p. 241-47, 1989.

28. RUBO, J. et al. Finite element análisis of stress distribuition on dental implants: A study of seven clinical variables. Part II - Stress on implants 
abutments and framework. Int. J. Prosthodontics, v. 12, n. 6, p. 567, 1999. /abstract/

29. SHAOAN, W.; HOBKIRK, J.A. Load distribuition on implants with a cantilevered superstructure: an in vitro pilot study. Implant Dentistry, v. 5, n. 1, p. 36-42, 1996.

30. SERTGÖZ, A. Finite element analysis study of the effect of superstructure material on stress distribution in an implant-supported fixed prosthesis. Int. J. Prosthodont., v. 10, n. 1, p. 19-27, Jan./Feb. 1997.

31.SERTGÖZ, A.; GÜVENER, S. Finite element analysis of the effect of cantilever and implant length on stress distribution in an implant-supported fixed prosthesis. J. prosth. Dent., v. 76, n. 2, p. 165-69, Aug. 1996.

32. SHACKLETON, J. et al. Prosthodontic complications and problems of fixture-supported prostheses. J. Dent. Res., v. 71, n. 4, p. 1113, 1992.

33. SKALAK, R. Biomechanical considerations in osseointegrated prostheses. J. prosth. Dent., v. 49, n. 6, p. 843-8, June 1983.

34. SKINNER - MATERIAIS DENTÁRIOS

35. SPIEKERMANN, $H$. et al. Biomechanics. In: . Color atlas of dental Medicine implantology. New York, Thieme Medical Publishers, 1995, p. 81-90.

36. STEGARIOU, R. et al. Influence of prosthesis material on stress distribuition in bone and implant: A 3-dimensional finite element abalysis. Int. J. oral Maxillofac. Implants, v. 13, n. 6, p. 781-90, 1998.

37. TAKAHASHI, Y. et al. Probability of failure of highly filled indirect resinveneered implant-supported restorations: An "in vitro" study. Int. J. Prosthodont., v. 15, n. 2, p. 179-82, 2002.

38. TAYLOR, T. D. et al. Implant Prosthodontics: current perspective and future directions. Int. J. oral Maxillofac. Implants, v. 15, n. 1, p. 66-75, 2000.

39. TOM, W. P.; JOHANN, A. R. Influence of mandibular superstructure shape on implant stresses during simulated posterior biting. J. prosthet. Dent., v. 82, n. 1, p. 67-72, 1999. 
40. TURANO, J.C., TURANO, L.C. Fundamentos de prótese total. São Paulo: Livraria Editora Santos, 2002, p. 399-419.

41. VAN ZYL, P. P. et al. Three-Dimensional finite element model of a human mandible incorporating six osseointegrated implants for stress análisis of mandibular cantilever prostheses. Int. J. oral Maxillofac. Implants, v. 10, n. 1, p. 51-7, 1995.

42. WIE, H. Registration of localization, occlusion and occluding materials for failing screw joints in the Branemark implant system. Clin. oral Implants Res., v. 6, p. 47-53, 1995.

43. WHITE, S. N. et al. Effect of cantilever length on stress transfer by implantsupported prostheses. J. prosth. Dent., v. 71, n. 5, p. 493-99, 1994.

44. WILLIAMS, K.R. et al. Finite element analysis of fixed prostheses attached to osseointegrated implants. Quintessence Int., v. 21, n. 7, p. 563-70, July 1990.

45. WISKOTT, H.W.A. et al. "In vivo" wear of three types of veneering materials using implant-supported restorations: a method evaluation. Eur. J. oral Sci, v. 110, p. 61-67, 2002.

46.ZARB. G.A.; SCHMITT, A. The longitudinal clinical effectiveness of osseointegrated dental implants: the Toronto study. Part II: the prosthetic results. J. prosth. Dent., v. 64, n. 1, p. 53-61, Aug. 1990.

47.ZARB. G.A.; SCHMITT, A. The longitudinal clinical effectiveness of osseointegrated dental implants: the Toronto study. Part III: Problems and complications encountered. J. prosth. Dent., v. 64, n. 2, p. 185-94, Aug. 1990. 


\section{Bibliografia Consultada}

1.MOHL, D.M.; ZARB, G.A.; CARLSSON, L.D.S. Fundamentos de oclusão. 2 ed. São Paulo: Ed. Quintessence,1991. Cap. 10, p. 161-70.

2.HOBO, S., ICHIDA, E., GARCIA, L. Osseointegração e reabilitação oclusal. SãoPaulo: Livraria Editora Santos, 1997.

3.PHILLIPS, R.W. Materiais dentários de Skinner. Rio de Janeiro, Guanabara Koogan, 1993. 


\section{ABSTRACT}

The success of osseointegrated implants has a decisive influence of biomechanical aspects in wich implants, bone tissue and prosthesis are involved. The balance between the forces acting on this complex refer us to the diversity of methods and materials used to fabricate implant supported prosthesis.

The aim of this study was to verify the influence of aesthetic covering materials on the deformation of cantilevered frameworks.

Strain gauges were bonded to the inferior surface of a silver-palladium framework covered with ceramic and thermoacrylic resin on each of its two halves.

The framework was fixed to a metallic master model and a $35.2 \mathrm{~N}$ vertical static load was apllied to the free end at the distances of 10,15 and $20 \mathrm{~mm}$ distal to the terminal abutment.

The results showed that the use of a rigid material such as ceramic stiffen even more the framework, with consequently less deformation.

Another finding that was confirmed in this study was the direct influence of cantilever length on deformation of implant supported frameworks. 